\title{
Impact of Volatile and Semi-volatile Organic Compounds from Farming Environments on Allergy-Related Cellular Processes
}

\author{
Nadine Gawlitta ${ }^{1,2}$. Elias J. Zimmermann ${ }^{1,2}$ - Jürgen Orasche ${ }^{1}$. Anja Huber ${ }^{1}$. Jeroen Buters ${ }^{3,4}$. \\ Sebastiano Di Bucchianico ${ }^{1}$. Sebastian Oeder ${ }^{1}$. Thomas Gröger ${ }^{1} \cdot$ Ralf Zimmermann $^{1,2}$
}

Received: 20 May 2021 / Revised: 20 May 2021 / Accepted: 27 August 2021 / Published online: 29 September 2021

(c) The Author(s) 2021

\begin{abstract}
Allergic diseases are an increasing global burden. Epidemiological and in vivo studies showed that farming environments could protect from allergic asthma. Studies explaining this protective effect mainly focused on the influence of chemical compounds in the molecular size range of proteins and endotoxins. Our study aimed at deciphering the possible role of small-sized semi-volatile organic compounds (SVOCs) of farming aerosols in immunomodulation processes. Bronchial epithelial BEAS-2B cells were exposed to aerosol extracts of particulate matter $\left(\mathrm{PM}_{2.5}\right)$ from farming environments. These cell exposures revealed a decisive effect of the smaller sized fraction $(<3 \mathrm{kDa})$ compared to extracts including the larger sized fraction. We demonstrated that smaller compounds can induce regulations of inflammatory and allergy-related genes including interleukin-8, xanthine dehydrogenase and toll-like receptor 2 (TLR2). Additionally, we performed a comprehensive chemical investigation of two typical farming aerosols (cow vs. sheep) by applying comprehensive gas chromatography coupled to time-of-flight mass spectrometry. We were able to identify several SVOCs characteristic for the protective cow sheds environment including four key components. Cell exposure with the two farming extracts showed a distinct regulation of the E3 ubiquitin ligase PELI2 gene and TLR2 by cow shed extracts. Finally, the regulation of TLR2 corresponded to the regulation that was observed after exposing cells to an artificial mixture of the four key components identified in the cow sheds. In summary, we were able to demonstrate the importance of smaller particle-bound SVOCs found in farming environments concerning their possible contribution to a protective farm effect.
\end{abstract}

Keywords Environmental aerosols $\cdot \mathrm{GC} \times \mathrm{GC}-\mathrm{ToFMS} \cdot \mathrm{PM}_{2.5} \cdot$ Cell exposure $\cdot$ Allergy $\cdot$ Gene expression

\section{Introduction}

During the last decades, the prevalence of allergies has been increasing worldwide (Haahtela et al. 2013). The most common respiratory allergies are rhinitis, conjunctivitis and sinusitis in the upper airways as well as asthma in the lower

Thomas Gröger

thomas.groeger@helmholtz-muenchen.de

1 Joint Mass Spectrometry Centre (JMSC), Cooperation Group Comprehensive Molecular Analytics, Helmholtz Zentrum München, Neuherberg, Germany

2 Joint Mass Spectrometry Centre (JMSC), Chair of Analytical Chemistry, University of Rostock, Rostock, Germany

3 Institute of Allergy Research, Helmholtz Zentrum München, Neuherberg, Germany

4 Center of Allergy \& Environment (ZAUM), Technical University Munich, Munich, Germany respiratory tract (Chary et al. 2018). According to the World Allergy Organization (WAO), 300 million people suffer from asthma and up to 400 million from rhinitis (Pawankar 2014).

Up to now, the prevalence of allergic disorders was mainly restricted to developed countries. Industrialization and lifestyle in association with biodiversity loss and increasing air pollution seem to contribute to this prevalence (Reinmuth-Selzle et al. 2017). A similar trend of allergy occurrence can now be observed in newly industrialized countries, also coinciding with lifestyle changes and industrialization (Haahtela et al. 2013).

Epidemiological cohort studies like "Protection against Allergy-Study in Rural Environments" (PASTURE) as well as "Prevention of Allergy-Risk Factors for Sensitization in Children Related to Farming and Anthroposophic Lifestyle" (PARSIFAL) show that children growing up in a farming environment have lower levels of atopic sensitization, hay fever and asthma in comparison to non-farmer children 
(Alfvén et al. 2006; Illi et al. 2012; Loss et al. 2012). Debarry et al. (2007) advocate that microbial richness in these environments trigger the immune system leading to this protective effect. Frei et al. (2018) demonstrated that the exposure to non-microbial $\mathrm{N}$-glycolylneuraminic acid played a role in the protection from airway inflammation in farmer children. Whether the protective effect originates only from microbes or whether non-microbial substances also play an important part in the protective effect is still under discussion. The GABRIEL study group aimed to identify specific features of the farming environment contributing to this effect. Types of animal breeding, cultivation and animal feeding were compared (Illi et al. 2012). Among several features evaluated, they identified the presence of cow and straw as well as the consumption of raw farm milk as the three most important factors concerning asthma protection (Illi et al. 2012).

Peters et al. (2006) were the first to present experimental evidence to support epidemiological studies in which the exposure to traditional farming environment prevented mice from allergen induced airway inflammation. It was shown that mice pretreated with dust extract were unresponsive to methacholine challenge, suppressed eosinophil and lymphocyte recruitment and reduced $\mathrm{IgE}$ titers in bronchoalveolar lavage (BAL) fluid. In contrast, low dose exposure of Lipopolysaccharide (LPS) prior to ovalbumin (OVA) treatments did not show any significant effects. Based on the same shed dust extracts Schuijs et al. (2015) demonstrated a protection against experimental house dust mite (HDM) induced asthma through the ubiquitin-editing enzyme A20 (TNFAIP3) in relation with farming environment. In this context, in vivo exposures of mice to LPS prior to HDM pre-treatment inhibited the development of several asthma features.

Previous studies mainly focused on the influence of endotoxins, proteins and bacterial species to explain this asthma-protective effect (Peters et al. 2006; Debarry et al. 2007; Schuijs et al. 2015). Only a few studies were conducted with a focus on volatile organic compounds (VOCs) from biological origin (Roduit et al. 2019; Depner et al. 2020). A recent study identified higher contents of butyrate and propionate in stool samples from farmer children compared to non-farmer infants indicated a smaller likelihood of sensitization to food or inhalant allergens by the age of 6 (Roduit et al. 2019). Our pilot study focused on a comprehensive characterization of possibly relevant chemical compounds found in the aerosols of farming environments concerning their immuno-modulatory effects. We applied a more tailored and controlled sampling method to obtain well-defined aerosol samples (Inhalable fraction: $\mathrm{PM} \leq 2.5 \mu \mathrm{m}$ and the gas phase) and, thus, to be able to mimic a rather realistic situation of an inhalative exposure. While volatiles directly enter the respiratory tract through the gas phase, SVOCs enter the airways in both ways, either in the gas phase or particlebound, depending on their gas-to-particle-partitioning, which is related to volatility and surrounding conditions (Gkatzelis et al. 2018). As gas phase and particles with an aerodynamic diameter smaller than $2.5 \mu \mathrm{m}$ can deeply penetrate into the lung, volatiles and SVOCs can induce immune-regulatory reactions, thus, being potentially relevant in processes leading to allergic sensitization (Hussain et al. 2011; Hartl et al. 2018).

To evaluate the influence of farming aerosols on lung epithelial cell responses, we prepared extracts from the collected $\mathrm{PM}_{2.5}$ samples and used these for in vitro cell exposures. As epithelial cells are the first instance of contact to allergens and particles in the respiratory tract, these cells are crucial as first defense mechanisms when protecting the respiratory system from harmful inhalable substances (Hartl et al. 2018). We, thus, exposed human bronchial epithelial BEAS-2B cells to PM extracts containing different molecular size fractions (total or $<3 \mathrm{kDa}$ ). Subsequently, we evaluated their cytotoxicity as well as their immunological effects by analyzing expression levels of genes that are described in literature to be inducible by environmental PM samples and/or genes that have a direct or indirect effect on allergic sensitization, exacerbation or asthma development.

As the presence of cow but not sheep seems to be of major importance in asthma protection (Illi et al. 2012), we decided to sample in two cow sheds and two sheep sheds to compare these sampling sites. We were aiming at determining significant differences in the chemical pattern of inhalable $\mathrm{PM}_{2.5}$ SVOCs from the two distinct shed types and, in this context, to evaluate possible immune modulating effects of promising compounds. In this way, components only identified in cow sheds are assumed to contribute to the protective farm effect. Additionally, the effects of an artificial mixture of the four components, which were found to be specific for cow (protective) but not sheep sheds (non-protective), were compared to the gene regulations caused by cow shed extracts.

As VOCs and SVOCs of the gas phase could also induce immunomodulation processes, we additionally sampled and comprehensively characterized the gas phase components of a possibly protective cow shed environment. We, thus, targeted the 20 most abundant gas phase components in the cow sheds and verified their potential immunomodulating characteristics by literature research. 


\section{Methods}

\section{Particulate Matter}

\section{Sampling}

Sampling of the particulate phase was conducted on a High Volume Digitel Sampler DH-80 (Digitel, Switzerland) with a pre-impactor to remove particles larger than $2.5 \mu \mathrm{m}$. Sampling material was quartz fiber filters (QFF, T293, Munktell, Sweden), which were pre-treated at $550{ }^{\circ} \mathrm{C}$ for $5 \mathrm{~h}$ prior use. Shed samples were taken in a height of $2 \mathrm{~m}$ and in a distance of at least $2 \mathrm{~m}$ from animals as well as barn doors. Background samplers were built up upwind to reduce the influence of shed aerosols on the ambient air samples. Sampling was carried out daily for $24 \mathrm{~h}$ at a flow of $500 \mathrm{~L} \mathrm{~min}^{-1}$. PM samples were taken in four different animal sheds. Aluminium foil was cleaned by acetone (Roth, ROTISOLV $\geq 99.9 \%$ GC Ultra Grade) and used to store the filters at $-20{ }^{\circ} \mathrm{C}$ until analysis. Further information on other sampling parameters as well as characteristics of sheds and animal type can be found in Table S1. Field blanks, filters that were stored in the sampler without any sampling flow, were taken in- and outside of the sheds at every sampling campaign.

\section{Sample Preparation for Chemical Profiling}

PM samples were prepared at the day of analysis. QFF were cut by defined punches and placed into glass inserts for the direct thermal desorption unit for analysis. These glass inserts were deactivated with trimethylchlorosilane (TMCS, fisher scientific, Germany) prior use. The analyzed filter corresponded to $1 \mathrm{~m}^{3}$ (seven times $d=2 \mathrm{~mm}$ Punch) of shed aerosol. $1 \mu \mathrm{L}$ of an internal standard (ISTD), $1 \mu \mathrm{L}$ of a derivatization standard (DSTD) and $10 \mu \mathrm{L}$ of the silylation reagent N-Methyl-N-(trimethylsilyl)trifluoroacetamide (MSTFA, fisher scientific, Germany) were applied to the QFFs by an autosampler (Shimadzu AOC-5000 Plus) prior analysis (see Table S2 for further information). In-situ Derivatization and Thermal Desorption (IDTD) was conducted. Further details on the methodology of IDTD can be found in previous papers (Orasche et al. 2011; Weggler et al. 2016).

\section{Sample Analysis}

SVOCs of PM were analyzed on a GC $\times$ GC-ToFMS system (Agilent 6890 Gas Chromatograph equipped with a LECO Pegasus 4D ToF MS). For programmable temperature vaporization (PTV) desorption an Optic 3 injection system (ATAS GL, Netherlands) was used (See further information in Tables S3 and S4). SVOCs were first separated on a polar column (BPX50, SGE, Australia) and subsequently focused and released onto a second non-polar column (BPX1, SGE, Australia) by a modulator. Afterwards, SVOCs were transferred into a mass spectrum, where they were ionized at $70 \mathrm{eV}$ and analyzed. Sample blends and field blanks were measured in triplicates in a block randomized manner. Besides the main measuring sequence, one sampling week of cow shed A was measured day-to-day. The area of each filter sample was $0.9 \mathrm{~m}^{3}(d=5 \mathrm{~mm})$. The analysis corresponded to previous descriptions. More information on chromatographic and mass spectral parameters can be found in Tables S5-S7.

\section{Data Processing}

Samples were pre-processed with ChromaTOF (LECO, Version 4.50.8.0 optimized for Pegasus). Following steps were conducted: Baseline correction, peak find, library search, area calculation, classifications and application of references. Afterwards, data was exported as.csv-file in a distinct structure and was normalized with MatLab (Version 2013b) (Table S2). Data was aligned and compared with OpenChrom (Lablicate, Edition 1.4.0.202002200817). Analysis of variances-principal component analysis (ANOVAPCA, $p<0.001$ ) was used for statistical evaluation. Further information on data processing and data handling can be found in Tables S8-S9.

\section{Gas Phase}

\section{Sampling}

Gas phase samples were taken from the same sheds as PM samples. Samplers were placed correspondingly to PM samplers except for a sampling height of $1 \mathrm{~m}$. Adsorber tubes were sampled on a Gas phase sampler (DESAGA, Sarstedt Group, GS 301) for $24 \mathrm{~h}$ at a flow of $0.5 \mathrm{~L} \mathrm{~min}^{-1}$. A filter holder assembly made of stainless steel and equipped with a quartz fiber filter was used for cutting of particles and protecting the adsorbers. The adsorber tubes were packed with three sublayers of graphitized carbon black (GCB) sorbents used to trap compounds of several volatility ranges (Table S10). One adsorber tube was kept closed and taken as field blank for every sampling campaign. Samples were stored at $-20^{\circ} \mathrm{C}$ until analysis.

\section{Sample Analysis}

The analysis of the adsorber tubes was done by thermal desorption (TD) with a Shimadzu TD-20 thermal desorption unit (Shimadzu, Japan), coupled to a GC-MS System (Shimadzu GCMS-QP2010 Ultra, Shimadzu, Japan). The analysis was done according to Mason et al. (Mason et al. 2020), 
but modified to the applied GCB adsorbent material. Samples were spiked with an isotope labelled standard mixture. The thermal desorption was performed at $345^{\circ} \mathrm{C}$ and lasted $45 \mathrm{~min}$. Extracted compounds were at first concentrated on a Tenax TD trap, cooled at $5{ }^{\circ} \mathrm{C}$ and then redesorbed at $330{ }^{\circ} \mathrm{C}$ and transferred with a split ratio of 10 to the gas chromatograph. Separation was done on a $30 \mathrm{~m}$ long BP20 polar column $(0.25 \mathrm{~mm} \mathrm{ID} \times 0.25 \mu \mathrm{m} \mathrm{df}, \mathrm{SGE}$, Australia) Further information on temperature program of GC analysis and mass spectral parameters can be found in Table S11.

\section{Data Processing}

Raw data files were imported to OpenChrom (Lablicate, Edition 1.4.0.202002200817) as *cdf-files. Peak detection, integration and identification were applied (Table S12).

\section{Filter Extraction for Submerged Cell Exposure}

Filter punches, which equaled a sampling volume of $800 \mathrm{~m}^{3}$ shed aerosol, were prepared for every shed. Filters were extracted with methanol (MeOH, Roth, ROTISOLV, $\geq 99.9 \%$ GC Ultra Grade, Germany) in an ultrasonic bath (Palssonic, Ultrasonic Cleaner, ALLPAX, Germany) for $15 \mathrm{~min}$. This step was performed three times in a row, exchanging the solvent every time to enable a high extraction efficiency. Next, all extracts were centrifuged twice at room temperature and $4000 \mathrm{rpm}$ (2660 rcf) for $15 \mathrm{~min}$ (Universal $320 \mathrm{R}$, Hettich Zentrifugen). The supernatant was first filtered with a PTFE filter with a pore-size of $1 \mu \mathrm{m}$ (Zefluor, Supported PTFE, PALL Life Sciences, USA) and subsequently with a PTFE filter of a pore-size of $0.2 \mu \mathrm{m}$ (PTFE, Sartorius Stedim Biotech, Germany). Extracts were concentrated at $50{ }^{\circ} \mathrm{C}$, at $80 \mathrm{rpm}$ and under $135 \mathrm{mbar}$ (Büchi Syncore coupled to a Büchi Vac V-513 and Büchi Vacuum Controller V-800) to approximately $1 \mathrm{~mL}$. Afterwards extracts were transferred to $5 \mathrm{~mL}$ vials and dried under gaseous nitrogen. Samples were stored at $-20{ }^{\circ} \mathrm{C}$. Vials were weighed empty and containing dried extracts to enable the determination of the amount of the extracts.

\section{Size Filtration}

The dried extracts were resolved in $400 \mu \mathrm{L} \mathrm{MeOH} / \mathrm{H}_{2} \mathrm{O}$ (60/40 MilliQ Reference A+). Extracts were size filtrated by cellulose filters with a cut in molecular weight of $3000 \mathrm{Da}$ (Merck, Amicon Ultra, $0.5 \mathrm{~mL} 3 \mathrm{~K}$ ). For this purpose, cellulose filters were pre-cleaned with $0.1 \mathrm{M} \mathrm{NaOH}$ (SigmaAldrich, reagent grade $\geq 98 \%$ pellets anhydrous) solution and centrifuged (Universal $320 \mathrm{R}$, Hettich Zentrifugen) at $10,000 \times g$ and room temperature for $5 \mathrm{~min}$. This step was performed four times in a row. Afterwards, $\mathrm{H}_{2} \mathrm{O}$ (MilliQ Reference $\mathrm{A}+$ ) was used as last pre-cleaning step, centrifuged at
$10,000 \mathrm{~g}$ and room temperature for $5 \mathrm{~min}$ as well. Now, the solved extracts were filled into the cellulose filters and centrifuged at $14,000 \times g$ and room temperature for $40 \mathrm{~min}$. The smaller fraction was collected in a tube. Then, the filter was put upside down in a new tube and centrifuged at $1000 \times g$ and room temperature for $2 \mathrm{~min}$ to collect the fraction larger than $3000 \mathrm{Da}$. Both fractions were transferred into different glass vials and dried under gaseous nitrogen. Only the small fraction (containing molecules $<3 \mathrm{kDa}$ ) was used for further experiments.

\section{Chemical Reference Material}

A stock solution of 4Z,7Z,10Z,13Z,16Z,19Z-Docosahexaenoic acid (DHA, Santa Cruz Biotechnology, USA), Dehydroisoandrosterone 3-sulfate sodium (Sigma-Aldrich, Germany), 2-Nonadecanone (Santa Cruz Biotechnology, USA) and Cholesta-3,5-diene (Santa Cruz Biotechnology) was solved in DMSO (Dimethylsulfoxide, ROTH, $\geq 95.5 \%$ BioScience-Grade, Germany). Afterwards, BEGM cell culture medium (as described below) was used to dilute the standard mixture to a concentration of $0.5 \%$ DMSO. Final concentration of 4Z,7Z,10Z,13Z,16Z,19Z-Docosahexaenoic acid, Dehydroisoandrosterone 3-sulfate sodium, 2-Nonadecanone and Cholesta-3,5-diene were $1.3 \mu \mathrm{g} \mathrm{mL}^{-1}, 1.45 \mu \mathrm{g} \mathrm{mL}^{-1}$, $0.25 \mu \mathrm{g} \mathrm{mL}^{-1}$ and $2.0 \mu \mathrm{g} \mathrm{mL}^{-1}$, respectively. Additionally, the stock solution of the standards was diluted with Bronchial Epithelial Growth Medium (BEGM, Lonza Inc., USA) by a factor of 1000 .

\section{Endotoxin Test}

The endotoxin levels in the total and filtered $(<3 \mathrm{kDA})$ samples were assayed using Pierce LAL Chromogenic Endotoxin Quantitation Kit (Thermo Scientific, USA) according to manufactures instructions. The amount of detected endotoxin was in all samples below $0.046 \mathrm{EU} \mathrm{mL}^{-1}$ ( $\left.0.0046 \mathrm{ng} \mathrm{mL}^{-1}\right)$ (Table S13).

\section{Cell Culture}

The human bronchial epithelial cell line BEAS-2B was obtained from American Type Culture Collection (ATCC® CRL-9609' ${ }^{\mathrm{TM}}$, USA) and cultivated in BEGM supplemented with penicillin $\left(100 \mathrm{U} \mathrm{mL}^{-1}\right)$ and streptomycin $\left(0.1 \mathrm{mg} \mathrm{mL}^{-1}\right)$. BEAS-2B cells were cultured in $75 \mathrm{~cm}^{2}$ tissue culture flasks (Sigma-Aldrich, Germany) and 24-well cell culture plates (Corning, USA) pre-coated with $0.01 \mathrm{mg} \mathrm{mL}^{-1}$ fibronectin (Sigma-Aldrich, Germany), $0.03 \mathrm{mg} \mathrm{mL}^{-1}$ bovine collagen Type 1 (Gibco, USA) and $0.01 \mathrm{mg} \mathrm{mL} \mathrm{m}^{-1}$ Bovine Serum Albumin (BSA, SigmaAldrich, Germany). Cells were maintained at $37^{\circ} \mathrm{C}$ in a $5 \%$ 
$\mathrm{CO}_{2}$ atmosphere and were passaged every $2-3$ days before reaching confluency.

\section{Cell Exposure}

BEAS-2B cells were plated on 24 well cell culture plates $24 \mathrm{~h}$ prior to exposure at a cell density of $9 \times 10^{4} \mathrm{cells} \mathrm{cm}^{-2}$ for the $4 \mathrm{~h}$ incubation and $4.2 \times 10^{4}$ cells cm $\mathrm{cm}^{-2}$ for the $24 \mathrm{~h}$ incubation. Shed extracts were solved in DMSO and BEGM was added to a final concentration of $0.5 \%$ DMSO in BEGM. Different shed extract concentrations were prepared by diluting with BEGM and 0.5\% DMSO to keep the DMSO concentration in all samples constant. For the exposure, BEAS-2B cells were treated with different shed extract concentrations $\left(0,15.6,125,500 \mu \mathrm{g} \mathrm{mL}^{-1}\right)$ or standard mixture concentrations $\left(0,0.005,5 \mu \mathrm{g} \mathrm{mL}^{-1}\right)$ for 4 or $24 \mathrm{~h}$ at $37^{\circ} \mathrm{C}$ in a $5 \% \mathrm{CO}_{2}$ atmosphere.

\section{Cytotoxicity Assay—Lactate Dehydrogenase (LDH) Release Assay}

Cytotoxicity induced by the treatment was assessed by LDH leakage into the treatment medium. Following 4 and $24 \mathrm{~h}$ exposure, $200 \mu \mathrm{L}$ treatment medium was collected and $50 \mu \mathrm{L}$ was used for quantification of released LDH (two technical replicates). An LDH detection kit was used in accordance with the manufacturer's instructions (Roche, Germany). The absorbance of the reaction mix was measured at $490 \mathrm{~nm}$ with a microplate reader (Varioskan LUX, Thermo Scientific). Cell-free treatment medium was used to generate blank values, which were subsequently subtracted from the samples. From cells kept under untreated conditions, the supernatant was collected before they were lysed with $2 \%$ Triton-X 100 (Roth, Germany) for $20 \mathrm{~min}$ prior to the end of the exposure. By mixing the supernatant of the lysed cells with the prior collected supernatant, samples with the highest available released LDH were generated and measured values were set to $100 \%$ toxicity.

\section{Gene Expression Assay}

Following treatment, the supernatant was completely removed and total RNA of the cells was isolated with MN NucleoSpin RNA/Protein KIT (Macherey-Nagel, Germany) according to the manufacturer's protocol. Total RNA collected from BEAS-2B cells was analyzed by UV/VIS-spectrophotometer measurement using a Nanodrop One (Thermo Scientific, USA). RNA was stored at $-80{ }^{\circ} \mathrm{C}$ no longer than 4 weeks. cDNA was synthesized from 250 ng total RNA by reverse transcription in a $20 \mu \mathrm{L}$ reaction using a high-capacity cDNA Reverse Transcription Kit with RNase Inhibitor (Applied Biosystems, USA) following the manufacturer's instructions. After the cDNA synthesis, the cDNAs were diluted to a concentration of $5 \mathrm{ng} \mu \mathrm{L}^{-1}$ with nuclease-free water. Real-time PCR was performed (QuantStudio 3, Applied Biosystems) in a total volume of $11 \mu \mathrm{L}$ containing $2 \mu \mathrm{L}$ cDNA, $3.5 \mu \mathrm{L}$ nuclease-free water, $5 \mu \mathrm{L}$ TaqMan Universal mastermix and $0.5 \mu \mathrm{L}$ TaqMan Gene Expressions assay per reaction. The expression of each gene of interest (HSPAIA, XDH, HMOX1, PELI2, TLR2, TNFAIP3, CXCL8, $C Y P 1 A 1)$ in each sample was normalized against housekeeping genes (GUSB, GAPDH) and expressed as fold change compared to the untreated control as calculated by the delta delta Ct method (Livak and Schmittgen 2001). More information on genes and their corresponding TaqMan assays used can be found in Table S14.

\section{Data Processing of Gene Expression Experiments}

Raw data was analyzed and illustrated using Excel 2016 (Microsoft), R-4.0.3 (R-Project), RStudio (Version 1.1.463, RStudio, Inc). Statistical analysis was performed in R. In all cases a Levene test was used to test for variance homogeneity between the different groups or samples. In case of similar variances, an ANOVA was used followed by Tukey's honestly significant difference (HSD) test. Pairwise comparison was performed with a two-tail $t$-test. A Welch's two-tail $t$ test was applied when variances were inhomogeneous. Adobe Illustrator (Creative Suite 6) was used for figure illustration.

\section{Results and Discussion}

\section{Differentiated View on the Gene Expression Caused by the Exposure with Cow Shed Extracts of an Extensive Molecular Size Range Compared to the $<3 \mathrm{kDa}$ Fraction}

Herein, we evaluate the effects of small chemical compounds on the transcriptional regulation of inflammatory, oxidative stress-related and immunomodulatory genes and compare these with the ones caused by the whole extract. For this purpose, we sampled particle-bound SVOCs in a possibly allergy-protective farming environment and compared the gene expression of the overall SVOC composition with the one caused by the fraction containing smaller molecules solely. SVOCs were extracted with methanol from the filter material (total molecular size fraction, $\mathrm{CS}-\mathrm{A}_{\mathrm{T}}$ ). The smaller fraction $\left(\mathrm{CS}-\mathrm{A}_{\mathrm{S}}\right)$ was isolated due to a centrifugal size filtration with a cellulose filter $<3 \mathrm{kDa}$ from CS- $\mathrm{A}_{\mathrm{T}}$. CS- $\mathrm{A}_{\mathrm{T}}$ and CS-A $\mathrm{A}_{\mathrm{S}}$ were used for submerged cell exposure studies at different exposure times $(4$ and $24 \mathrm{~h})$ and different concentrations $\left(15.6 \mu \mathrm{g} \mathrm{mL} \mathrm{g}^{-1}, 125 \mu \mathrm{g} \mathrm{mL} \mathrm{m}^{-1}, 500 \mu \mathrm{g} \mathrm{mL}{ }^{-1}\right)$.

A set of genes was selected for expression analysis to enable the evaluation of the influence of shed extracts on cellular functions with a focus on allergy related immunomodulating 
processes. Inflammation, oxidative stress, xenobiotic metabolism and general cellular stress were addressed by interleukin-8 (CXCL8), heme oxygenase 1 (HMOX1), cytochrome P450 1A1 (CYP1Al) and heat shock $70 \mathrm{kDa}$ Protein 1A (HSPA1A), respectively. Tumor Necrosis Factor AlphaInduced Protein 3 (TNFAIP3) and xanthine dehydrogenase $(X D H)$ were already presented as immunomodulating regulators. The importance of TNFAIP3, also known as A20, in the context of allergies and asthma was previously addressed by Schuijs et al. (2015). XDH is crucial for the production of uric acid, which is able to induce T helper 2 (Th2) immunity and is altered in asthmatics (Kool et al. 2011; Hara et al. 2014; Gold et al. 2016; Huff et al. 2017). Finally, gene regulations of TLR2 and PELI2 were investigated to further evaluate allergy related cellular responses (Jin et al. 2012; Zakeri and Russo 2018; Dai et al. 2020).

Following genes showed similar regulations for the total extract $\left(\mathrm{CS}-\mathrm{A}_{\mathrm{T}}\right)$ as well as the smaller fraction $\left(\mathrm{CS}-\mathrm{A}_{\mathrm{S}}\right)$ after in vitro cell exposure: HMOX1, HSPA1A, CYPIA1 and $X D H$. The oxidative stress marker HMOXI and the general stress marker HSPAIA were slightly upregulated by both samples after $4 \mathrm{~h}$ and $24 \mathrm{~h}$ exposure (Fig. 1). Xenobiotic metabolism, represented by the regulation of CYP1Al, was strongly increased by both samples after $4 \mathrm{~h}$ (tenfold) and $24 \mathrm{~h}$ (300-fold) (Fig. 1). Furthermore, a concentration dependent trend for CS- $\mathrm{A}_{\mathrm{T}}$ and CS-A $\mathrm{A}_{\mathrm{S}}$ for both time points could be observed (Fig. S1).

$X D H$ was downregulated by CS- $\mathrm{A}_{\mathrm{T}}$ and CS-A $\mathrm{A}_{\mathrm{S}}$ after $4 \mathrm{~h}$ (Fig. 1A). An upregulation of $X D H$ by the lowest concentration $\left(15.6 \mu \mathrm{g} \mathrm{mL}^{-1}\right)$ of the total extract and the smaller fraction after $4 \mathrm{~h}$ could be observed (Fig. 1). These regulations show a significant dose-dependency for CS- $\mathrm{A}_{\mathrm{T}}(p<0.01)$ and CA- $\mathrm{A}_{\mathrm{S}}(p<0.01)$ (Fig. 1c). The regulation pattern of $\mathrm{XDH}$ seems, thus, to be highly reliant on the exposed concentration by specific environmental substances. Moreover, the downregulation of $\mathrm{XDH}$ by the highest concentration equals the regulations found by Huff et al. (2017) after treatment with $\mathrm{XDH}$ inhibitor allopurinol or ABCC4 inhibitor MK-571. Both decreased uric acid production in human airway epithelial cells (Huff et al. 2017). XDH produces uric acid, a damage associated molecular pattern (DAMP) secreted by human airway epithelial cells. It was previously hypothesized, that the production of uric acid depends on environmental stimuli associated with chronic respiratory diseases (Huff et al. 2017). Huff et al. (2017) demonstrated that HDM stimulates uric acid production in vitro as well as in vivo. Moreover, extracellular levels of uric acid were augmented in culture of primary human epithelial cells from asthma patients. The combination of the pro-inflammatory cytokines tumor necrosis factor $\alpha$ (TNF- $\alpha$ ) and interferon $\gamma(\mathrm{IFN}-\gamma)$ promoted extracellular uric acid levels and $X D H$ gene expression in human epithelial cells (Huff et al. 2017). Gold et al. (2016) demonstrated, that in vivo exposure of mice by $\mathrm{PM}_{10}$ and $\mathrm{HDM}$, the latter highly related to allergic sensitization, induced mucosal production of uric acid.

The regulation patterns of $C X C L 8, T N F A I P 3$ and TLR2 showed distinct regulations of CS- $\mathrm{A}_{\mathrm{T}}$ compared to CS-A . $_{\mathrm{S}}$. The inflammation marker CXCL8 was strongly downregulated by CS- $\mathrm{A}_{\mathrm{S}}$ and only slightly downregulated by CS- $\mathrm{A}_{\mathrm{T}}$ after $4 \mathrm{~h}$ (Fig. 1A). In contrast, a pronounced upregulation of threefold by CS- $\mathrm{A}_{\mathrm{T}}$ and no regulation by CS- $\mathrm{A}_{\mathrm{S}}$ can be observed after $24 \mathrm{~h}$ (Fig. 1B). A significant dose dependency for $C X C L 8$ was noticeable for the lowest concentration $\left(15.6 \mu \mathrm{g} \mathrm{mL}^{-1}\right)$ compared to the highest concentration $\left(500 \mu \mathrm{g} \mathrm{mL}^{-1}\right)$ for both samples CS-A $\mathrm{T}_{\mathrm{T}}(p<0.05)$ and CS-A $(p<0.001)$ after $4 \mathrm{~h}$ exposure (Fig. 1a).

TNFAIP3 showed an upregulation for CS- $\mathrm{A}_{\mathrm{T}}$ after $4 \mathrm{~h}$ and $24 \mathrm{~h}$, while no regulation for the corresponding concentration of CS-A $\mathrm{A}_{\mathrm{S}}$ could be observed (Fig. 1). Additionally, a significant dose dependent upregulation for $15.6 \mu \mathrm{g} \mathrm{mL}$ and $500 \mu \mathrm{g} \mathrm{mL}^{-1}$ of CS-A $\mathrm{A}_{\mathrm{T}}(p<0.05)$ after $4 \mathrm{~h}$ exposure time can be found (Fig. 1b). TNFAIP3, also known as A20, has already been demonstrated to be an important endpoint in the protection against asthma after HDM challenge (Schuijs et al. 2015). Our data indicates that this gene is mainly regulated by larger components of the farming extracts, which were excluded from CS- $\mathrm{A}_{S}$ by the filtration step. This can be supported by literature, as the following paper describes similar effects resulting from the larger fraction of shed extracts (Schuijs et al. 2015).

As LPS on its own can regulate TNFAIP 3 and $C X C L 8$ in a similar way as the cow shed extracts (Fig. S2), we tested our complete sample set for endotoxins to ensure that the regulations observed are not caused by LPS (endotoxin), but by other components found in the shed extracts. We obtained, independent of the shed type, endotoxin values below the detection limit of the test (Table S13). Consequently, none of the gene regulations observed were induced by endotoxins.

$T L R 2$ was slightly upregulated by CS-A $\mathrm{A}_{\mathrm{T}}$ after $4 \mathrm{~h}$ of exposure, while it was downregulated by the corresponding concentration of CS-A (Fig. 1A). After $24 \mathrm{~h}$, a slight upregulation for both samples CS-A $\mathrm{A}_{\mathrm{T}}$ and $\mathrm{CS}-\mathrm{A}_{\mathrm{S}}$ can be noticed (Fig. 1B). Having a closer look at the dose dependency of all concentrations used of CS- $\mathrm{A}_{\mathrm{T}}$ and CS-A $\mathrm{A}_{\mathrm{S}}$ after $24 \mathrm{~h}$ exposure, a similar trend is indicated for both samples, while only the $15.6 \mu \mathrm{g} \mathrm{mL}^{-1}$ in comparison to $125 \mu \mathrm{g} \mathrm{mL}^{-1}$ of CS- $\mathrm{A}_{\mathrm{T}}$ showed a significant difference $(p<0.05)$ (Fig. 1d). The regulation of TLR 2 was, thus, not only depending on the smaller fraction but seems to be regulated by other higher molecular weight compounds as well. Toll-like receptors (TLRs) are type 1 transmembrane receptors found on the plasma membrane and are expressed among others by epithelial cells. It is suggested that microbial products activate TLRs in a way that exerts their suppressive effect against allergic diseases (Zakeri and Russo 2018). The manipulation of TLRs in the control of asthma, thus, became highly 


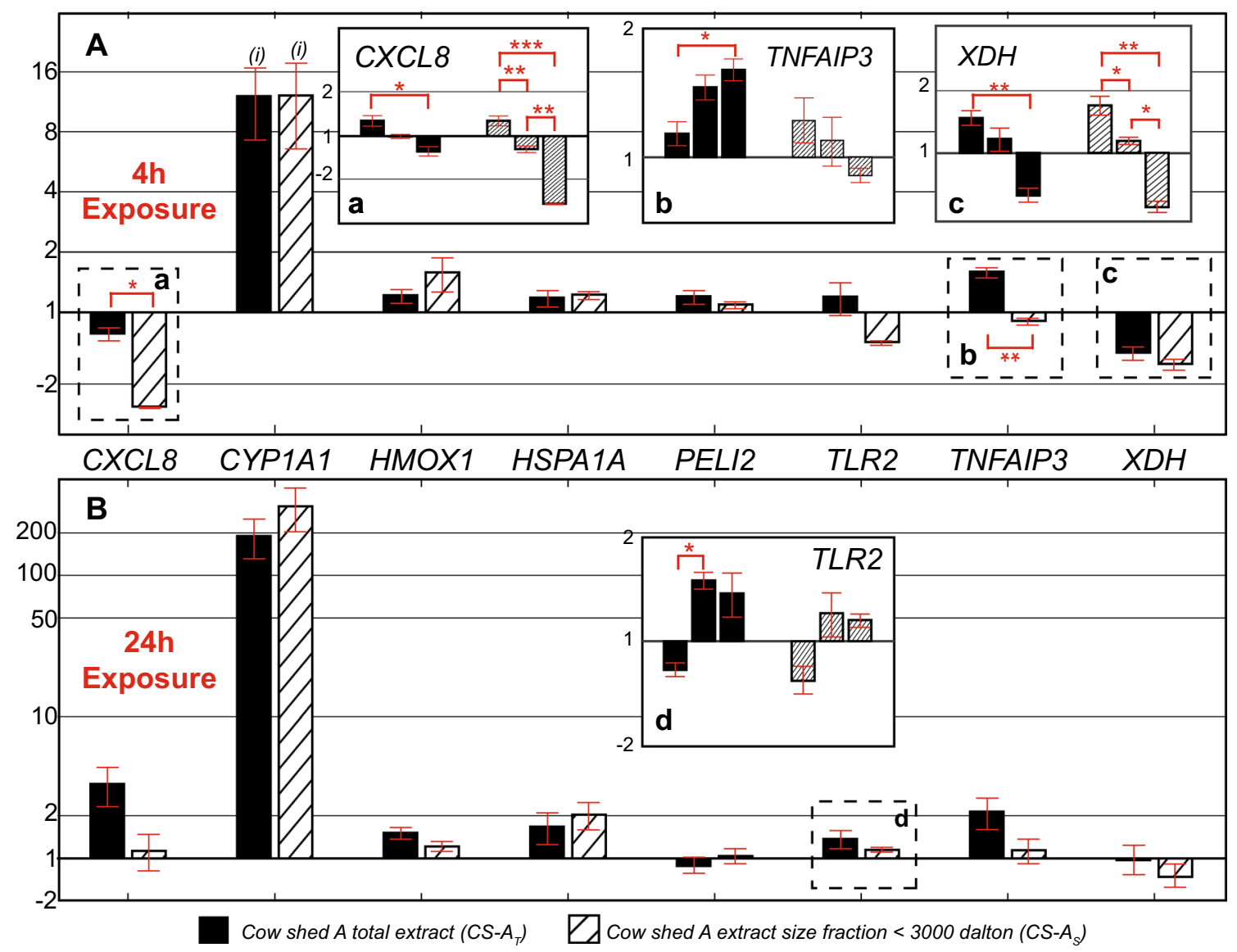

Fig. 1 A Molecular size in shed aerosol extracts matters: Gene expression regulations by $500 \mu \mathrm{g} \mathrm{mL}^{-1}$ extract concentration of $\mathrm{CS}-\mathrm{A}_{\mathrm{T}}$ (total extract) and CS-A $\mathrm{A}_{\mathrm{S}}$ (extract only with molecules $<3000 \mathrm{Da})$ after $4 \mathrm{~h}$ cell exposure. CXCL8 was significantly $(p<0.05)$ stronger downregulated by the by $500 \mu \mathrm{g} \mathrm{mL}^{-1}$ of $\mathrm{CS}-\mathrm{A}_{\mathrm{S}}$ compared to CS- $\mathrm{A}_{\mathrm{T}}$. TLR2 was slightly downregulated by CS-A $\mathrm{S}$, but not by CS- $\mathrm{A}_{\mathrm{T}}$ after $4 \mathrm{~h}$. TNFAIP3 was upregulated by CS- $\mathrm{A}_{\mathrm{T}}$ after $4 \mathrm{~h}$, which was significantly different $(p<0.01)$ compared to the regulation caused by CS-A $\mathrm{A}_{\mathrm{S}}$. a Significant dose-dependency of the regulation of $C X C L 8$ after $4 \mathrm{~h}$ for $C S-\mathrm{A}_{\mathrm{T}}$ and $\mathrm{CS}-\mathrm{A}_{\mathrm{S}}$. While the regulation by $C S-A_{T}$ was only significant for $15.6 \mu \mathrm{g} \mathrm{mL}^{-1}$ compared to $500 \mu \mathrm{g} \mathrm{mL}^{-1}(p<0.05)$, all concentrations tested for CS-A showed significant regulations $\left(15.6 \mu \mathrm{g} \mathrm{mL} \mathrm{m}^{-1}\right.$ and $500 \mu \mathrm{g} \mathrm{mL} \mathrm{mL}^{-1}$, $p<0.001 ; 15.6 \mu \mathrm{g} \mathrm{mL}^{-1}$ and $125 \mu \mathrm{g} \mathrm{mL}^{-1}, p<0.01 ; 125 \mu \mathrm{g} \mathrm{mL}^{-1}$ and $\left.500 \mu \mathrm{g} \mathrm{mL}^{-1}, p<0.01\right)$. b Significant $(p<0.05)$ dose-dependency of the regulation of TNFAIP 3 after $4 \mathrm{~h}$ for $\mathrm{CS}-\mathrm{A}_{\mathrm{T}}$ but not CS-A $\mathrm{A}$. $\mathrm{c}$ Significant dose-dependency of the regulation of $X D H$ after $4 \mathrm{~h}$ for CS- $\mathrm{A}_{\mathrm{T}}$ and CS- $\mathrm{A}_{\mathrm{S}}$. While the regulation by CS- $\mathrm{A}_{\mathrm{T}}$ was only significant for $15.6 \mu \mathrm{g} \mathrm{mL} \mathrm{m}^{-1}$ compared to $500 \mu \mathrm{g} \mathrm{mL} \mathrm{mL}^{-1}(p<0.01)$, all concentrations tested for $\mathrm{CS}^{-\mathrm{A}_{\mathrm{S}}}$ showed significant regula-

relevant. Depending on the study conducted, TLR2 showed either pro- or anti-allergic effects (Zakeri and Russo 2018). Concerning studies on the anti-allergic effect of $T L R 2$ it was demonstrated that $T L R 2$ activation attenuated allergic inflammation in an OVA and HDM-sensitized mice model (Haapakoski et al. 2013, Zakeri and Russo 2018). tions $\left(15.6 \mu \mathrm{g} \mathrm{mL}^{-1}\right.$ and $500 \mu \mathrm{g} \mathrm{mL}^{-1}, p<0.01 ; 15.6 \mu \mathrm{g} \mathrm{mL} L^{-1}$ and $125 \mu \mathrm{g} \mathrm{mL}^{-1}, p<0.05 ; 125 \mu \mathrm{g} \mathrm{mL}^{-1}$ and $\left.500 \mu \mathrm{g} \mathrm{mL}^{-1}, p<0.05\right)$. B Gene expression regulations by $500 \mu \mathrm{g} \mathrm{mL} \mathrm{m}^{-1}$ extract concentration of $\mathrm{CS}^{-\mathrm{A}_{\mathrm{T}}}$ (total extract) and CS- $\mathrm{A}_{\mathrm{S}}$ (extract only with molecules $<3000 \mathrm{Da}$ ) after $24 \mathrm{~h}$ cell exposure. The upregulation of $C X C L 8$ was highly pronounced by $C S-\mathrm{A}_{\mathrm{T}}$ but not by CS-A after $24 \mathrm{~h}$. TNFAIP3 is still upregulated by CS-A $\mathrm{A}_{\mathrm{T}}$ after $24 \mathrm{~h}$, but not by $C S-A_{S}$. The comparison of the regulations of the different time points showed a significant $(p<0.05)$ higher upregulation of CYP1A1 by CS-A $\mathrm{A}_{\mathrm{T}}$ and CS-A $\mathrm{A}_{\mathrm{S}}$ after $24 \mathrm{~h}$ compared to $4 \mathrm{~h}$ exposure time. d A dose-dependent trend can also be shown for TLR2 by 15.6 and $125 \mu \mathrm{gL} \mathrm{mL}^{-1}$ of CS-A $\mathrm{A}_{\mathrm{T}}$ and CS- $\mathrm{A}_{\mathrm{S}}$, but is only significant for CS- $\mathrm{A}_{\mathrm{T}}(p<0.05)$. For $\mathbf{a}, \mathbf{b}, \mathbf{c}$ and $\mathbf{d}$ concentrations tested for every sample were from left to right: $15.6 \mu \mathrm{g} \mathrm{mL}-125 \mu \mathrm{g} \mathrm{mL}$ and $500 \mu \mathrm{g} \mathrm{mL}^{-1}$. Mean and standard error of the mean $(n=3)$ of every sample are depicted. Significances indicated for the comparison of different concentrations and different shed types $* p<0.05$, $* * p<0.01, * * * p<0.001$. Significances indicated for the comparison of different time points (i): $p<0.05$

The ubiquitination related gene PELI2 showed potentially slight regulations for the highest concentration of CS- $\mathrm{A}_{\mathrm{T}}$ and $\mathrm{CS}-\mathrm{A}_{\mathrm{S}}$ after $4 \mathrm{~h}$ and $24 \mathrm{~h}$ exposure. These regulations were so low, though, that they will not be further discussed in the comparison of CS- $\mathrm{A}_{\mathrm{T}}$ and CS-A $\mathrm{A}_{\mathrm{S}}$. 


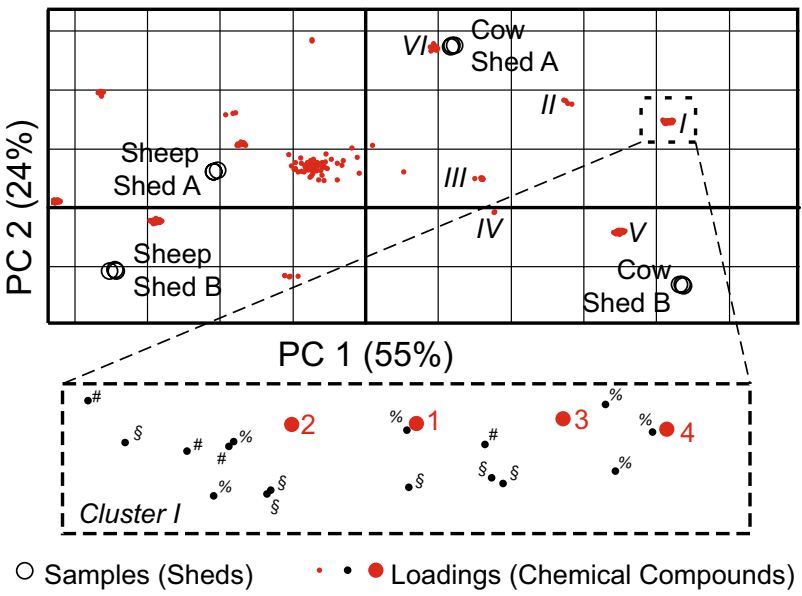

Fig. 2 Scores and loadings plot $(p<0.001)$ of the four different sheds. Sheep sheds (left) and cow sheds (right) are separated along principal component 1 (PC1). Individual sheds are differentiated along principal component 2 (PC2). Corresponding loadings plot with important clusters (I-VI) involving cow sheds (right). I: Components only found in cow sheds A and B. II: Components found in both cow sheds and sheep shed A. III: Components found in both cow sheds and sheep shed B. IV: Components found in cow shed B and sheep shed A. V: Components found in cow shed B only. VI: Components found in cow shed A only. \#Contamination/blank/inconclusive mass spectrum, §Highly abundant in ambient air samples, \% not confirmed by daily measurements

These results indicate distinct immune modulating effects of the smaller fraction when focusing on probably allergy protective effects of farming environments.

\section{Identification of Differences in the Chemical Profile of PM-Bound SVOCs Found in Distinct Farming Environments}

Literature demonstrated the importance of distinct factors contributing to the protective farm effect (Illi et al. 2012). One of these factors is the type of animal stabled in the farm. In this aspect, the presence of cows seems to be highly relevant. We, thus, aimed to find SVOCs specific for cow sheds (protective) in comparison to sheep sheds (non-protective).

The following non-targeted analysis via $\mathrm{GC} \times \mathrm{GC}$ led to a comprehensive fingerprint of the SVOC composition of the inhalable $\mathrm{PM}_{2.5}$ samples of cow versus sheep sheds without focusing on single targets. A derivatization agent was used to enable the analysis of more polar substances (Orasche et al. 2011; Weggler et al. 2016). Although, every shed was sampled for one week only, the use of blends of all seven sampling days (six for sheep shed B) enabled a correction for daily variances.

Our technique detected about 700 SVOC compounds to be present on the particles. A subsequent ANOVA-PCA from the found signals aimed the evaluation of differences between cow and sheep sheds (Further information on data processing and statistical evaluation utilized can be found in Tables S8 and S9). The PCA separated the shed types along principal component 1 (PC1), which explained over $55 \%$ of the variances in the samples (Fig. 2). The remaining variances captured by the following PC did not indicate an association to our experimental design.

The resulting loadings plot allowed the identification of significant differences of the chemical pattern of SVOC composition between cow and sheep (Fig. 2). The most relevant loadings for the cow sheds are displayed in distinct groups (I-VI). These clusters differentiate depending on the influence of the different sheds. As cluster I showed the highest loadings towards the cow sheds (PC1) and only contained substances being present in both cow but not in the sheep sheds, we expected this cluster to consist of compounds highly specific for this environment (further information on cluster II-VI in Table S15).

To confirm the relevance of these substances and exclude non-shed-related influences, we took background ambient air samples of $\mathrm{PM}_{2.5}$ and analyzed them likewise. Thereby, we identified that seven out of 20 sample components of cluster I could also be found in the ambient air samples showing an identical or higher abundance than in the shed itself (Table S17). Some of these components are common secondary organic aerosols (SOA) like 6,6-dimethyl,(1R)-bicyclo[3.1.1]heptan-2-one, originating, e.g. from $\beta$-pinene (Mutzel et al. 2016). These components were, thus, not investigated any further. By performing an additional ANOVA-PCA including the background samples, we confirmed that the chemical discrimination mainly results from compounds originating from the sheds (Fig. S3).

Furthermore, we excluded compounds that were found in blank measurements or of which identification was inconclusive from further evaluation (Table S17). The analysis of daily measurements enabled the confirmation of four key components with them being present in at least six out of seven individual samples (Table 1).

We focused on the evaluation of these four key compounds, as they were highly specific for the cow shed environment. A first tentative identification of these key compounds was conducted by comparing the mass spectra with the Natural Institute of Standardization (NIST) library. A similarity of at least 700 was applied as hit criteria (Table S18, Figs. S4, S5). For further validation of the qualitative assignment and the subsequent quantitative determination, we analyzed commercially available standard material.

The identity of dehydroisoandrosterone sulfate (DHEAS) could be confirmed by the standard measured. This clear identification allowed us to apply the standard addition approach for quantification. We determined a concentration of $12 \mathrm{ng} \mathrm{m}^{-3}$ of DHEA-S in the samples from cow shed A. Dehydroisoandrosterone (DHEA) is a very common natural steroid prohormone of estrogen and androgen. It is 


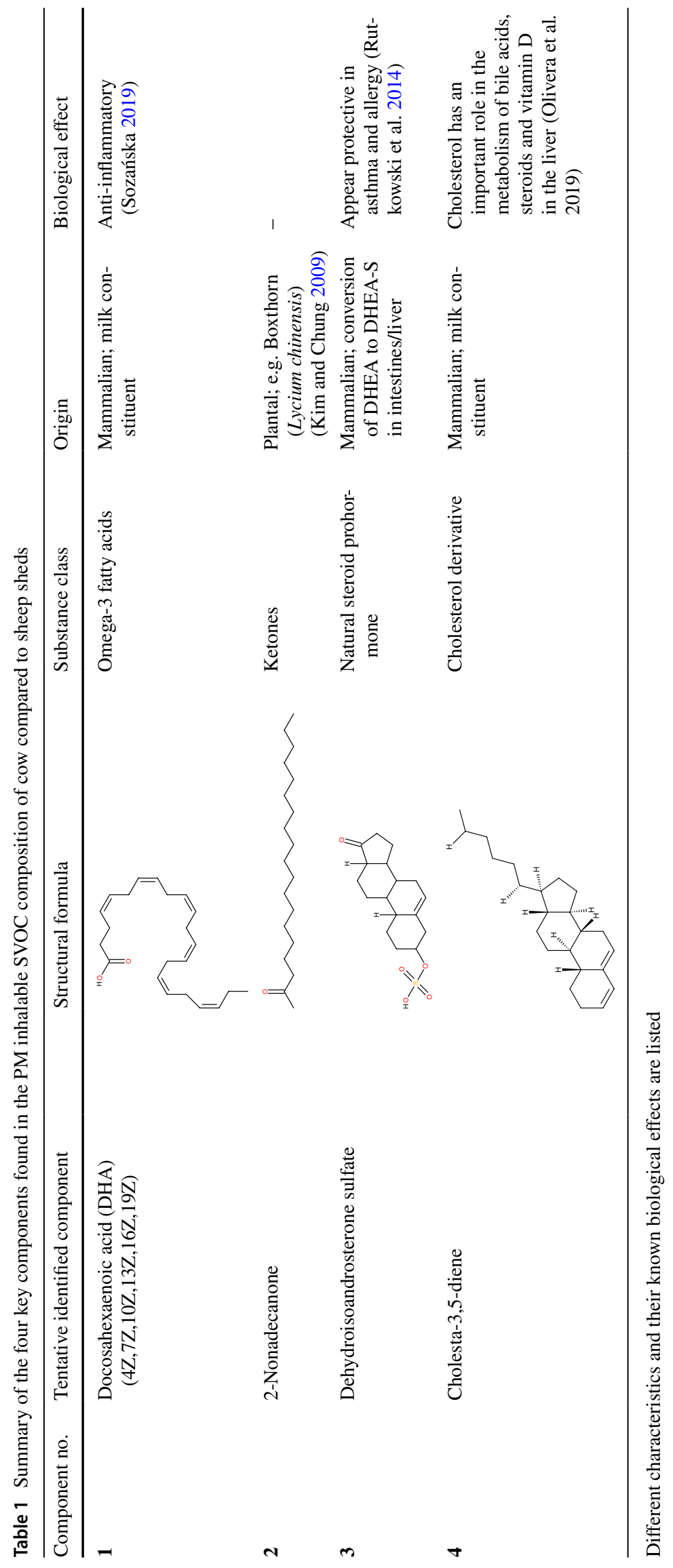


an example of steroids metabolized from cholesterol and is endogenously sulfated in the liver and the intestines to DHEA-S, which is the most available form in the body. For several years now, DHEA is in discussion for replacing corticosteroids in asthma treatment (Koziol-White et al. 2012). Ample research has been conducted to explain the immune modulating and anti-inflammatory effects of DHEA/DHEA$S$ in animals and humans (Kasperska-Zajac 2010). Previous studies showed that DHEA-S attenuated OVA-induced airway inflammation by decreasing eosinophilic infiltration into the lungs and inhibiting the increase in eotaxin- 1 and eotaxin-2, IL-5, IL-13, IL-6 and TNF- $\alpha$ expression (Koziol-White et al. 2012). Moreover, it was demonstrated that DHEA also decreased HDM-induced eosinophil flux, IL-4 and IL-5 levels into the lungs as well as IL-10, IL-5 and IFN- $\gamma$ production. Overall, DHEA and its metabolite DHEA$S$ have been confirmed to attenuate cytokine-induced hyperresponsiveness of airway smooth muscle, to inhibit chemotaxis and chemokinesis of the cells in animal studies and, finally, to inhibit immune cell recruitment to the lungs following allergen challenge (Koziol-White et al. 2012). These properties seem to be very promising in allergy protection and should further be investigated in vitro as well as in vivo studies. Another important context of DHEA-S and allergy protection might be the time of exposure to these substances. Throughout the first 6 years of life, DHEA-S concentrations are usually very low in humans, whereas a higher incidence of allergic sensitization can be observed (Yu et al. 1999; Kasperska-Zajac 2010; Pyrhönen et al. 2019). This indicates that low DHEA-S concentrations could partly promote allergic sensitization. Higher exposure to DHEA-S early in life might, thus, contribute to an allergy protective effect. In our study, DHEA-S was only present in cow sheds but not in sheep sheds. The more pronounced protective effect in the presence of cows might therefore be partly dependent on early life exposure to DHEA-S, leading to higher concentrations in the body and, therefore, to lower probabilities of allergic sensitization of the child (Kasperska-Zajac 2010).

The key compound tentatively identified as 2-Nonadecanone eluted after the native standard in the first dimension. However, the characteristic chromatographic region of similar ketones and the fit of the mass spectrum suggests that the sample component is a ketone with a slightly longer alkyl chain. The Cholesta-3,5-diene standard eluted later than the sample component implying that the alkyl chain of the sample component might be shorter or not present at all. Although, the exact isomeric composition of 2-Nonadecanone and Cholesta-3,5-diene could not be confirmed by standard material, the assignment of the substance class was valid. An external three-point calibration was applied to estimate the order of magnitude of these compounds present in the samples of cow stable A. We calculated an amount of roughly $0.5 \mathrm{ng} \mathrm{m}^{-3}$ for 2-Nonadecanone and $239 \mathrm{ng} \mathrm{m}^{-3}$ for Cholesta-3,5-diene.

To our knowledge, 2-Nonadecanone and Cholesta-3,5-diene were not mentioned in relation with allergies and asthma so far. Generally, cholesterol is an important component of different cell membranes. Maintenance of fluidity and participation in cell differentiation and proliferation are examples for its essential functions in cells (Olivera and Luengo 2019). In mammals, steroid hormones, bile acids and other steroids are produced from cholesterol. While the synthesis of these substances is restricted to mammals, the biodegradation of these compounds seems to be performed by bacteria only (Olivera and Luengo 2019).

Retention time information as well as spectral information for compound $\mathbf{1}$ did not allow us to clearly confirm its identity. Due to this uncertainty, we did not calculate any concentration for this compound. For the sake of completeness, we discussed the two most plausible possibilities, namely the affiliation to the group of DHEA-S isomers, which was previously described, or the association to the group of omega-3-fatty acid. As omega-3 fatty acids are constituents of cow milk as well as human breast milk and both, the consumption of raw cow milk early in life and breastfeeding are well-known factors contributing to the protective effect, the presence of these fatty acids in the farming aerosol is of great interest (Lambrecht and Hammad 2017). It was demonstrated, that a higher content of anti-inflammatory omega-3 fatty acids was asthma protective (Sozańska 2019).

Furthermore, the omega-3 fatty acid DHA showed advantages in the treatment of lung inflammatory conditions such as asthma and COPD. These advantages were partially explained by omega-3 fatty acid derived specialized proresolving mediators (SPMs) such as resolvins, protectins and maresins (Nordgren et al. 2014). SPMs have anti-inflammatory and pro-resolving features (Nordgren et al. 2014). In the respiratory tract, it was shown that SPMs inhibit asthmatic airway hyperresponsiveness, improved acute lung injury and reduced inflammatory cytokine production associated with cigarette smoke exposure (Nordgren et al. 2014). As the consumption of raw farm milk and the exposure to a farming environment, especially to cows and straw, are the most important protective factors, the exposure to omega- 3 fatty acids of the gut and the lung microbiome or as we found direct inhalable from the cows, might contribute to this protection by influencing the overall microbiome composition (Illi et al. 2012). 


\section{Differentiated View on the Gene Expression Caused by the Exposure to Small Molecules from Different Farming Environments}

Following chemical characterization of SVOC composition from the different sheds, we aimed to evaluate the cytotoxicity and immune modulating effects of the different shed types. We focused on the smaller fraction of the SVOC profiles of $\mathrm{PM}_{2.5}$, in which we identified significant differences from cow to sheep sheds. We performed a centrifugal size filtration to exclude molecules larger than $3 \mathrm{kDa}$. These extracts from two cow sheds $\left(\mathrm{CS}-\mathrm{A}_{\mathrm{S}}, \mathrm{CS}-\mathrm{B}_{\mathrm{S}}\right)$ and two sheep sheds (SS-A $\mathrm{A}_{\mathrm{S}}$ SS-B $\mathrm{B}_{\mathrm{S}}$ ) were applied for submerged cell exposure studies for different exposure times (4 and $24 \mathrm{~h})$ and different concentrations $\left(15.6 \mu \mathrm{g} \mathrm{mL}^{-1}\right.$, $\left.125 \mu \mathrm{g} \mathrm{mL} \mathrm{m}^{-1}, 500 \mu \mathrm{g} \mathrm{mL}^{-1}\right)$. The cytotoxicity for all exposures, except the exposure with the highest concentration of $\mathrm{CS}^{-\mathrm{B}_{\mathrm{S}}}\left(500 \mu \mathrm{g} \mathrm{mL}^{-1}\right)$, was below $10 \%\left(\mathrm{CS}-\mathrm{B}_{\mathrm{S}} 14 \%\right.$ after $24 \mathrm{~h}$ exposure) (Fig. S6).

PELI2 and TLR2 displayed different regulations for cow and sheep shed extracts after $4 \mathrm{~h}$ exposure. For PELI2 we observe a slight upregulation for the concentration range tested for both cow sheds after $4 \mathrm{~h}$ (Fig. 3a). Except for the $125 \mu \mathrm{g} \mathrm{mL}^{-1}$ sample of SS-B S $_{\mathrm{S}}$ ither no or a slight downregulation of this gene can be noticed for both sheep sheds after $4 \mathrm{~h}$ (Fig. 3a). These distinct regulations of cow compared to sheep sheds are found to be highly significant $(p<0.001$, Fig. 3a). While the effect of the cow shed samples persists after $24 \mathrm{~h}$, the sheep shed samples with a concentration of $15.6 \mu \mathrm{g} \mathrm{mL}^{-1}$ and $125 \mu \mathrm{g} \mathrm{mL} \mathrm{m}^{-1}$ cause an upregulation (Fig. S7). PELI2 belongs to the group of "really interesting new genes" (RING) ubiquitin-activating ligases E3. These enzymes are thought to regulate signaling from TLRs and IL-1 receptors (Jin et al. 2012). The regulation of PELI2 might, therefore, directly influence the regulation pattern of $T L R 2$. TLRs are known to mediate the induction of innate immunity as first line of defense against infections (Jin et al. 2012). Our results display a downregulation for TLR2 after exposure to the $500 \mu \mathrm{g} \mathrm{mL}^{-1}$ extracts of CS-A $\mathrm{S}_{\mathrm{S}}$ and CS-B after $4 \mathrm{~h}$, while this receptor is slightly upregulated or not regulated for the corresponding concentrations of SS- $\mathrm{A}_{\mathrm{S}}$ and SS-B $\mathrm{B}_{\mathrm{S}}$, respectively (Fig. 3A). This effect is not persistent for the $24 \mathrm{~h}$ time point (Fig. 3B). Nevertheless, the difference in the short-term regulation pattern of TLR 2 might be a promising indicator for a distinct immune modulating effect of cow sheds compared to sheep sheds. Furthermore, a significant dose-dependency $(p<0.05)$ for 15.6 and $500 \mu \mathrm{g} \mathrm{mL}^{-1}$ of both cow shed extracts $\mathrm{CS}-\mathrm{A}_{\mathrm{S}}$ and $\mathrm{CS}-\mathrm{B}_{\mathrm{S}}$ can be displayed.

The prominent regulation pattern of CS-B $\mathrm{B}_{\mathrm{S}}\left(500 \mu \mathrm{g} \mathrm{mL} \mathrm{mL}^{-1}\right)$ for some genes has to be discussed in the context of higher cytotoxicity and higher amounts of xenobiotics found in this sample. CS- $\mathrm{B}_{\mathrm{S}}$ induced a significant $(p<0.01)$ upregulation of $H M O X 1$ after $4 \mathrm{~h}$ and $24 \mathrm{~h}$. Furthermore, CXCL8 was strongly upregulated by this sample after $24 \mathrm{~h}$, while the upregulation of CYPIAl was less pronounced compared to all other sheds (Fig. 3B). This behavior might be explained by the poly-aromatic hydrocarbon $(\mathrm{PAH})$ levels found in the sheds. PAHs can induce among other oxidative stress and inflammation in cells (Delfino et al. 2011). We were able to demonstrate that eleven targeted PAHs could be found in CS- $\mathrm{B}_{\mathrm{S}}$ and had significantly higher concentrations compared to all other sheds (Table S16). Thus, the chemical composition and the background influence of each of the sheds need to be kept in mind when discussing the overall biological response.

The remaining genes, some of which showed regulations caused by the smaller molecular fraction compared to the total extract (Fig. 1), did not show distinct regulation patterns for the different shed types (Fig. 3).

\section{Gene Expression Caused by an Artificial Mixture of the Four Key Components Identified in Cow Sheds}

Finally, we show the gene regulation caused by the four key components found in the cow shed extracts. Cell exposure was performed correspondingly to the exposure by shed extracts. Concentrations used were oriented towards concentrations found in the $\mathrm{GC} \times \mathrm{GC}$ analysis. We found, that the regulations of HMOX1, HSPAIA, XDH, TNFAIP 3 and $C X C L 8$ resemble the ones found by the exposure to extracts smaller than $3 \mathrm{kDa}$ (Fig. 4). The upregulation of CYPIAI was significantly less pronounced compared to the ones caused by the shed extracts, confirming the influence of other compounds of the shed background like PAHs as being highly relevant for this regulation. The regulations of PELI2 were less pronounced in comparison to the exposure by the cow shed extracts. Intriguingly, the regulation pattern of $T L R 2$ induced by the $5 \mu \mathrm{g} \mathrm{mL}{ }^{-1}$ standard mixture equals the regulations induced by both small sized cow shed extracts $\left(\mathrm{CS}-\mathrm{A}_{\mathrm{S}}, \mathrm{CS}-\mathrm{B}_{\mathrm{S}}\right.$ ) after $4 \mathrm{~h}$ (Fig. 2b, Fig. 4). We additionally observed a significant difference $(p<0.05)$ in the regulation pattern of TLR 2 after $4 \mathrm{~h}$ by both concentrations of the compounds mix. Consequently, the regulation pattern of TLR2 should be further investigated to identify mechanisms that might contribute to an allergy protective effect of specific farming environments. In summary, we were able to show similarities in the regulation patterns of the key components identified and the shed extract exposures. These findings indicate a potential role of the key components regarding the protective farm effect and they might, thus, be important targets for further investigations. 

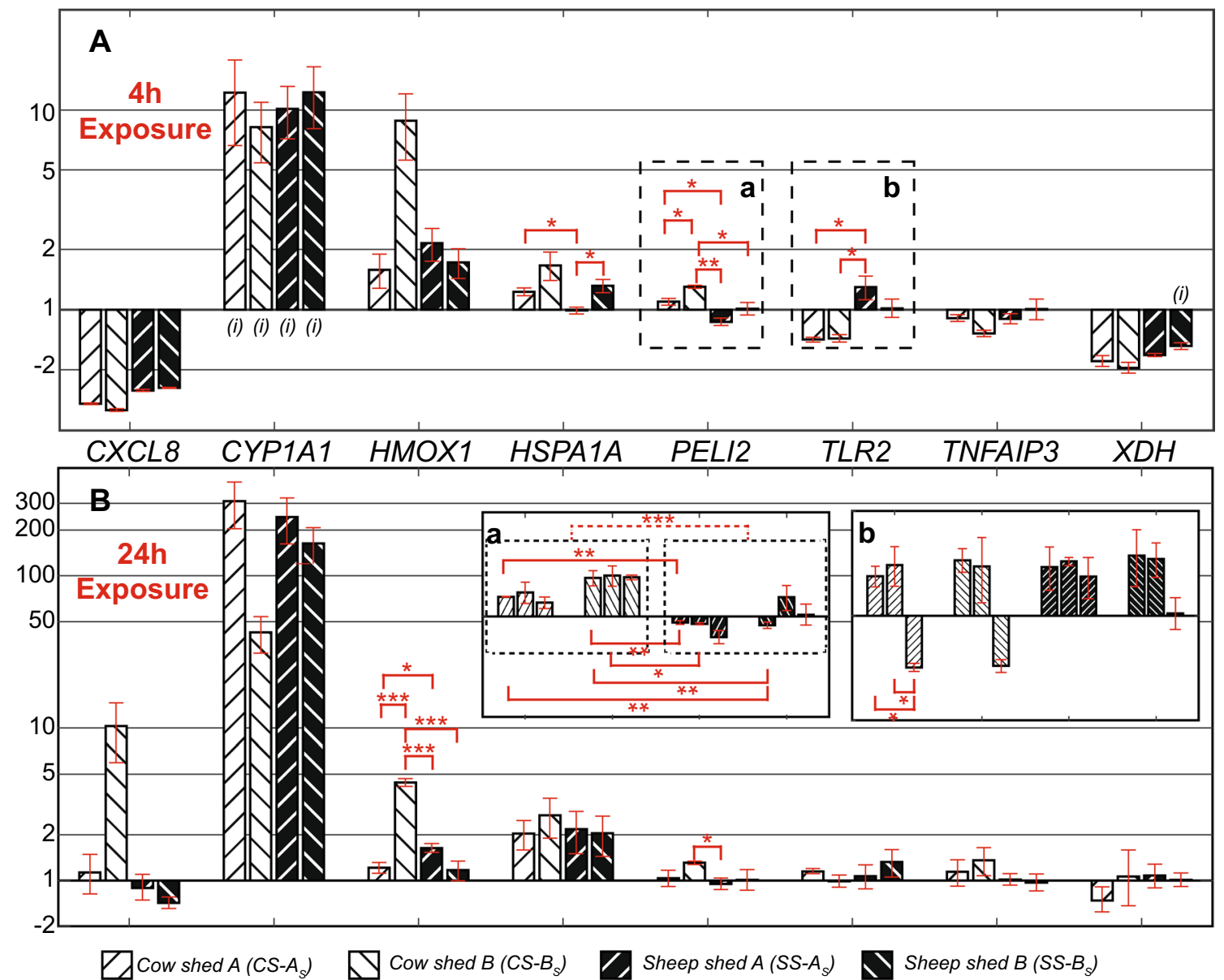

Fig. 3 A Biological effects of small molecules from aerosols sampled in cow and sheep sheds: Gene expression regulation by $500 \mu \mathrm{g} \mathrm{mL}^{-1}$ extract concentration of cow shed A $\left(C S-A_{S}\right)$, cow shed B $\left(C S-B_{S}\right)$, sheep shed A $\left(\mathrm{SS}-\mathrm{A}_{\mathrm{S}}\right)$ and sheep shed $\mathrm{B}\left(\mathrm{SS}-\mathrm{B}_{\mathrm{S}}\right)$ after $4 \mathrm{~h}$ exposure time. The exposure to cow and sheep shed extracts showed similar regulation patterns for most of the genes tested. PELI2 and TLR2 showed distinct regulation patterns in the comparison of cow and sheep shed extracts after $4 \mathrm{~h}$ exposure. The highest concentration of CS-A $\mathrm{A}_{\mathrm{S}}$ regulated PELI2 significantly different compared to CS- $\mathrm{B}_{\mathrm{S}}$ $(p<0.05)$ and SS-A $\mathrm{A}_{\mathrm{S}}(p<0.05)$, the highest concentration of CS-B $\mathrm{S}$ was significantly different regulated compared to SS-A $\mathrm{A}_{\mathrm{S}}(p<0.01)$ and $\mathrm{SS}^{-\mathrm{B}_{\mathrm{S}}}(p<0.5) . T L R 2$ was significantly different regulated by the $500 \mu \mathrm{g} \mathrm{mL} \mathrm{m}^{-1}$ sample from both cow sheds compared to SS-A $(p<0.05)$. a Regulations of PELI2 caused by all concentrations tested from all four shed extracts after $4 \mathrm{~h}$ exposure time. For the sake of clarity, significances for the $500 \mu \mathrm{g} \mathrm{mL}^{-1}$ samples are not shown again. The $15.6 \mu \mathrm{g} \mathrm{mL}^{-1}$ of CS-A $\mathrm{S}_{\mathrm{S}}$ and CS-B $\mathrm{B}_{\mathrm{S}}$ were significantly different compared to the same concentration of SS-A $\mathrm{A}_{S}$ and $S S-B_{S}$. The $125 \mu \mathrm{g} \mathrm{mL}^{-1}$ extract concentration of CS-B $\mathrm{B}_{\mathrm{S}}$ is also significantly different to the equivalent concentration of SS-A $\mathrm{A}_{\mathrm{S}}$. An overall comparison of the regulations caused by both cow sheds compared to both sheep sheds after $4 \mathrm{~h}$ exposure showed significant $(p<0.001)$ different shed type dependent regulations (dashed line). b Regulations of $T L R 2$ caused by all concentrations tested for all four shed extracts after $4 \mathrm{~h}$ exposure time. The highest concentration of CS-A $\mathrm{A}_{\mathrm{S}}$ and $\mathrm{CS}^{-\mathrm{B}_{\mathrm{S}}}$ shows a slight downregulation of TLR2 after $4 \mathrm{~h}$ in compar- ison to a slight upregulation and no regulation for the highest concentration of SS-A $\mathrm{A}_{\mathrm{S}}$ and $\mathrm{SS}-\mathrm{B}_{\mathrm{S}}$, respectively. Moreover, a significant dose-dependent regulation of TLR2 by $15.6 \mu \mathrm{g} \mathrm{mL}^{-1}, 125 \mu \mathrm{g} \mathrm{mL}-1$ and $500 \mu \mathrm{g} \mathrm{mL}^{-1}$ of CS-A $\mathrm{A}_{\mathrm{S}}$ and $\mathrm{CS}-\mathrm{B}_{\mathrm{S}}$ can be found. This regulation is found to be significant for $15.6 \mu \mathrm{g} \mathrm{mL}^{-1}$ compared to $125 \mu \mathrm{g} \mathrm{mL}$ $(p<0.05)$ and $125 \mu \mathrm{g} \mathrm{mL}^{-1}$ compared to $500 \mu \mathrm{g} \mathrm{mL}^{-1}(p<0.05)$ of CS-A $\mathrm{A}_{\mathrm{S}}$. The significances for the highest concentration tested for all samples are not displayed again. B Gene expression regulation by $500 \mu \mathrm{g} \mathrm{mL}^{-1}$ extract concentration of cow shed A $\left(\mathrm{CS}-\mathrm{A}_{\mathrm{S}}\right)$, cow shed $\mathrm{B}\left(\mathrm{CS}-\mathrm{B}_{\mathrm{S}}\right)$, sheep shed A $\left(\mathrm{SS}-\mathrm{A}_{\mathrm{S}}\right)$ and sheep shed B $\left(\mathrm{SS}-\mathrm{B}_{\mathrm{S}}\right)$ after $24 \mathrm{~h}$ exposure time. The exposure to cow and sheep shed extracts showed similar regulation patterns for most of the genes tested. The $500 \mu \mathrm{g} \mathrm{mL}^{-1}$ extract concentration of CS-B $\mathrm{s}_{\mathrm{s}}$ showed a distinct upregulation of $H M O X 1$ and $C X C L 8$ and a greatly less pronounced upregulation of $C Y P 1 A 1$ after $24 \mathrm{~h}$ exposure compared to the other shed extracts. The regulation of HMOX1 caused by CS- $\mathrm{B}_{\mathrm{S}}$ is highly significant $(p<0.001)$ compared to all other shed extracts. The comparison of the regulations of the different time points showed a significant $(p<0.05)$ higher upregulation of CYP1A1 by all shed extracts after $24 \mathrm{~h}$ compared to $4 \mathrm{~h}$ exposure time. For a and b concentrations tested for every sample were from left to right: $15.6 \mu \mathrm{g} \mathrm{mL}^{-1}$, $125 \mu \mathrm{g} \mathrm{mL}^{-1}$ and $500 \mu \mathrm{g} \mathrm{mL}^{-1}$. Mean value $(n=3)$ and standard error of the mean $(n=3)$ of every sample are depicted. Significances indicated for the comparison of different concentrations and different shed types $* p<0.05, * * p<0.01, * * * p<0.001$. Significances indicated for the comparison of different time points (i): $p<0.05$ 

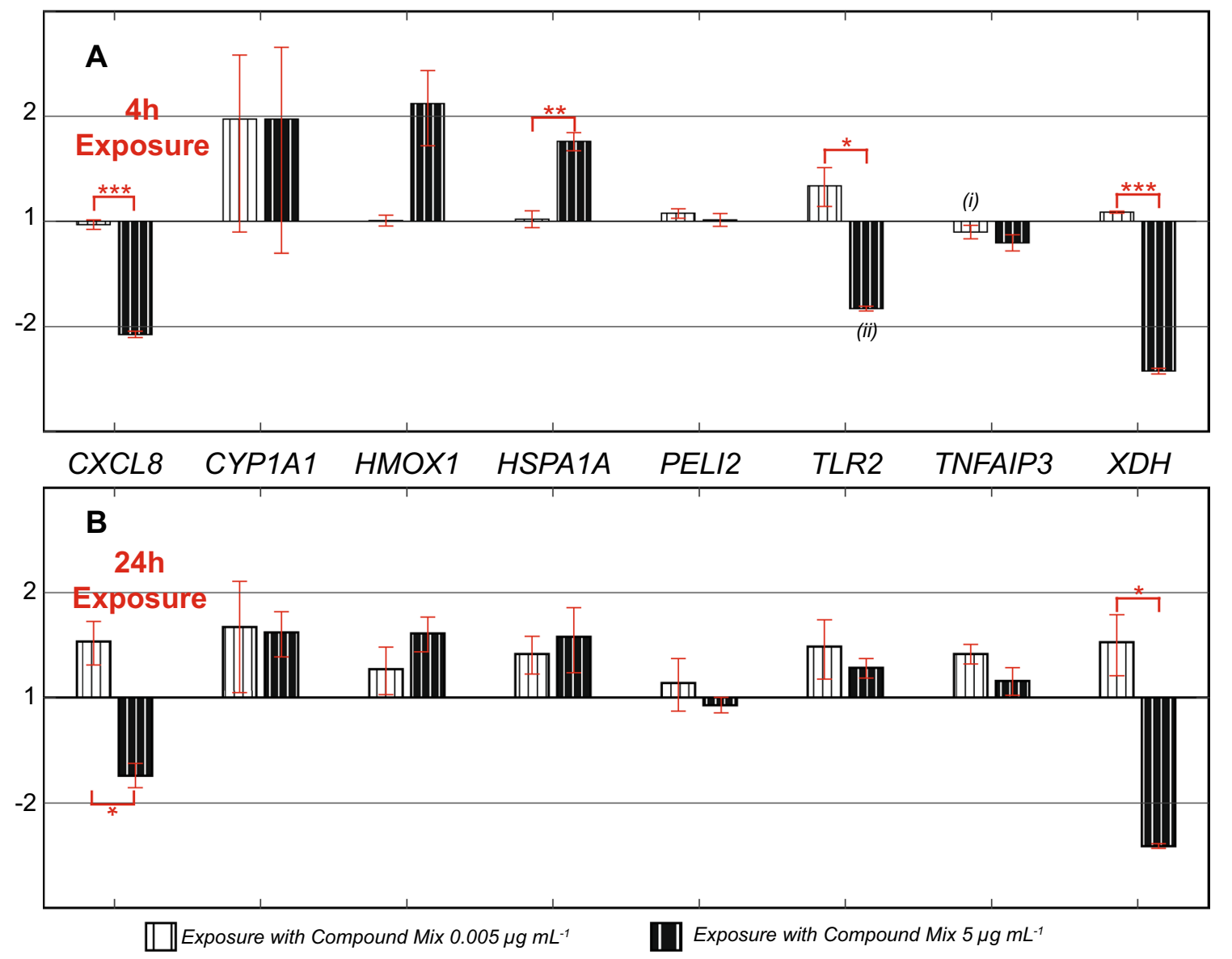

Fig. 4 A Gene expression regulation by a standard solution of the four cow-specific key components (1-4) after $4 \mathrm{~h}$ are displayed. Significant dose-dependent regulations can be found for CXCL8 $(p<0.001)$, HSPA1A $(p<0.01)$, TLR2 $(p<0.05)$ and XDH $(p<0.001)$ B Gene expression regulation by a standard solution of the four cowspecific key components (1-4) after $24 \mathrm{~h}$ are displayed. Significant dose-dependent regulations can be found for CXCL8 $(p<0.05)$ and $X D H(p<0.05)$ after $24 \mathrm{~h}$ exposure time. The comparison of the regulations of TLR2 at the different time points showed a distinct down-

\section{Characterization of Gas Phase Compounds Found in Cow Shed Environments}

With regard to the small molecular fraction, gaseous compounds must not be neglected. However, cell exposure to gaseous compounds requires other procedures compared to the exposure by PM-bound SVOCs. Due to the scope of the study, we decided to comprehensively characterize the smaller compounds found in possibly protective farming environments. For this purpose, we analyzed the gas phase components found in the two cow sheds and identified the 200 most prominent compounds of the gas phase via TD-GC-MS. As the amount of components is less than for PM, we only highlighted the 20 most abundant peaks detected in the two cow sheds and compared their biological relevance to the literature. Compounds with an inconclusive regulation for the $5 \mu \mathrm{g} \mathrm{mL} L^{-1}$ compound mix after $4 \mathrm{~h}$ and an upregulation after $24 \mathrm{~h}$, which is significant $(p<0.01)$. Another significant $(p<0.05)$ regulation can be observed for TNFAIP3 by $0.005 \mu \mathrm{g} \mathrm{mL} \mathrm{m}^{-1}$ compound mix by the comparison of the 4 and $24 \mathrm{~h}$ time point. Mean value $(n=3)$ and standard error of the mean $(n=3)$ of every sample are depicted. Significances indicated for the comparison of different concentrations and different shed types $* p<0.05$, $* * p<0.01$, $* * * p<0.001$. Significances indicated for the comparison of different time points (i): $p<0.05$, (ii): $p<0.01$

mass spectral identification and compounds found in less than four out of seven sampling days were excluded from further investigations. Highly abundant compounds from cow shed A and/or cow shed B and their possible origin are summarized in Table 2. Acetic acid and butanoic acid belong to the most prominent compounds. These compounds are classified as short chain fatty acids (SCFAs), which are discussed extensively in context of asthma and allergy protection (Tan et al. 2014; Cait et al. 2019; Roduit et al. 2019; Depner et al. 2020).

Recently, Depner et al. (2020) confirmed the importance of gut microbiome maturation (during the first year of life) and its contribution to the protective effect on childhood asthma. They recognized an inverse correlation of asthma and the amount of fecal butyrate of 12 months old infants. Butyrate, but also propionate contents, were significantly 
Table 220 most abundant volatile components of cow shed A and B, present in at least four out of seven samples, excluding unknowns, standard substances and substances found in field blanks

\begin{tabular}{|c|c|}
\hline VOCs & Origin \\
\hline \multicolumn{2}{|l|}{ SCFAs } \\
\hline Acetic acid ${ }^{\mathrm{b}}$ & Produced by bacterial fermentation \\
\hline \multicolumn{2}{|l|}{ Acetic acid, anhydride with formic acid ${ }^{\mathrm{a}}$} \\
\hline Acetic acid, butyl ester ${ }^{\mathrm{b}}$ & Acetate ester of butanol//metabolite \\
\hline Butanoic acid ${ }^{\mathrm{a}, \mathrm{b}}$ & Produced by bacterial fermentation \\
\hline \multicolumn{2}{|l|}{ Butanoic acid, ethyl ester ${ }^{\mathrm{a}}$} \\
\hline \multicolumn{2}{|l|}{ Butanoic acid, propyl ester ${ }^{\mathrm{b}}$} \\
\hline \multicolumn{2}{|l|}{ Hexanoic acid, ethyl ester ${ }^{b}$} \\
\hline Propionic acid ${ }^{\mathrm{a}}$ & Produced by bacterial fermentation \\
\hline \multicolumn{2}{|l|}{ Propionic acid, 2-hydroxy-, ethyl ester ${ }^{\mathrm{a}, \mathrm{b}}$} \\
\hline \multicolumn{2}{|l|}{ Terpenes } \\
\hline$(+)-2-$ Bornanone $^{\mathrm{b}}$ & Natural monoterpenoid//plant metabolite \\
\hline 3-Carene ${ }^{\mathrm{b}}$ & Natural terpene \\
\hline Bicyclo[3.1.1]hept-2-ene, 3,6,6-trimethyl- ${ }^{\mathrm{b}}$ & Natural terpene \\
\hline \multicolumn{2}{|c|}{$\begin{array}{l}\text { Table } 2 \text { summarizes SCFAs and Terpenes only, other VOCs can be found in Table S19 in the Supplemen- } \\
\text { tary Section }\end{array}$} \\
\hline \multicolumn{2}{|c|}{${ }^{\mathrm{a} B e l o n g s}$ to the 20 most abundant peaks of cow shed A } \\
\hline \multicolumn{2}{|c|}{${ }^{\mathrm{b}}$ belongs to the 20 most abundant peaks of cow shed $\mathrm{B}$} \\
\hline${ }^{\mathrm{a}} \mathrm{b}$ Belongs to the 20 most abundant peaks of & \\
\hline
\end{tabular}

higher in stool samples from 12 months old infants growing up on a farm compared to stool samples from non-farmer infants of the same age (Depner et al. 2020). A study by Roduit et al. (2019) confirmed that higher SCFAs, especially butyrate and propionate, in farmer infants indicated a smaller likelihood of sensitization of these to food and/or inhalant allergens by the age of 6 . To evaluate whether the increased intake of SCFAs might prevent from allergies and asthma, they orally administered SCFAs to mice and observed lower allergic airway inflammation during sensitization challenge. The authors suggested that not only an increased fiber intake but also the direct intake of SCFAs might contribute to allergy and asthma protection and might therefore be an interesting allergy prevention strategy (Roduit et al. 2019). Depner et al. (2020) proposed that a certain change in the gut microbiome composition by SCFAs might contribute to an asthma protective effect. We further assume that the exposure of lung microbiome by the released SCFAs in certain animal sheds, is pronouncing the possibly protective effect. This corresponds with previous observations describing a protective farm effect that was highly depended on the consumption of farmer nutrients, especially milk, and which was even more pronounced when children were exposed to animal sheds (Depner et al. 2020).

Terpenes were as well very prominent compounds of the gas phase. They are, besides aromatic and aliphatic constituents, major components of essential oils (EOs). EOs are very complex mixtures consisting of 20 to 60 different components, the two to three major components, though, are expected to characterize their overall biological activity. In nature, they are important in the protection of plants with their antibacterial, antiviral and antifungal properties. Inhalation of lipophilic constituents of EOs have been mentioned to inhibit microbial growth. 2-Bornanone, also known as camphor, which is a typical terpene found in many plants, was highly abundant in our samples from cow shed B. EOs [of the Artemisia L. genus] with a high camphor content were shown to have antifungal and antibacterial activities. An analysis of the antifungal properties of camphor alone confirmed an inhibition of certain fungal species (Abad et al. 2012).

In the context of respiratory diseases, EOs are very promising natural compounds because of their high volatility, their anti-microbial as well as anti-inflammatory properties. In a small study, Cohen and Dressier (1982) have already presented improvements of spirometric parameters after inhalation of an eucalyptus EO (9\%), camphor (35\%) and menthol (56\%) mix by adults suffering from cold-inhaled air. Eucalyptol (1,8-cineole) is a component already wellstudied and known to have not only anti-microbial and antiinflammatory but also bronchodilator properties (Horváth and Ács. 2015).

Since then, there has been a growing interest in the positive effects of 1,8-cineole in airway inflammatory disease. 1,8-cineole has been demonstrated to have anti-inflammatory effects comparable to prednisone in patients with severe asthma (Lee et al. 2016). Prednisone is a synthetical glucocorticoid with an immunosuppressive effect that is used for the treatment of asthma and other respiratory diseases. 
As the effects of 1,8-cineole seem to be highly relevant in airway inflammation treatment, we were targeting this terpenoid oxide in our cow shed samples. In cow shed B, 1,8-cineole could be confirmed in all seven samples, whereas in cow shed A 1,8-cineole was only found in one sample. Moreover, other EO substances as D-limonene, camphene, campholenal, $\alpha$-pinene, pinon and acetophenone can be found significantly (in at least four out of seven samples) in cow shed B, but not in cow shed A. These differences can be explained by seasonal alterations. While volatiles of cow shed A were sampled during winter times, volatiles of cow shed B were sampled in summer time.

Besides terpenes and SCFAs, other substances were identified in the cow sheds, which cannot be assigned to any of the previously mentioned categories (Table S19). Moreover, we identified six different highly abundant air pollutants in the sheds (Table S19). In contrast to our PM samples, air pollutants of the gas phase originate from local anthropogenic sources. These anthropogenic sources can likely be narrowed down to the tractors used for example to provide fodder for the cows. For cow shed A, the main pollutants found were benzene, benzoic acid and 4-methyl-benzoic acid, cow shed B showed a high abundance of toluene, followed by 1,3,5-trimethyl-benzene and p-xylene.

\section{Conclusion}

In vitro cell exposures revealed distinct regulation pattern for CXCL8, TNFAIP3 and TLR2 by the low-molecular weight fraction $(<3 \mathrm{kDa})$ compared to the total extract of shed dust. The importance of the low molecular compounds directed us to focus on the aerosol composition of different farming environments. In this context, we evaluated the chemical composition of particle-bound SVOCs from cow sheds compared to sheep sheds. We identified several components as being specific for cow sheds including four key components. Gene expression data of the smaller faction of cow compared to sheep shed extracts showed similar regulation patterns for most of the genes exposed. A distinct regulation of the E3 ubiquitin ligase PELI2 gene and TLR2 is indicated when comparing gene expression data of cow and sheep shed extracts. Furthermore, in vitro exposures to an artificial mixture, consisting of the four key components identified in particle-bound SVOC composition of the cow sheds, regulated the TLR2 gene correspondingly to the smaller fraction of the cow shed extracts. Finally, gas phase components of the cow sheds were analyzed to comprehensively characterize this specific farming environment. In summary, we demonstrated the importance of the smaller inhalable compounds found in farming environments and their possible contribution to an overall protective effect. Future studies should include gas phase components for cell exposure experiments as literature presented that these substances could also induce immunomodulatory effects and could, thus, contribute to allergy protection.

Supplementary Information The online version contains supplementary material available at https://doi.org/10.1007/s12403-021-00429-1.

Acknowledgements The authors thank LECO Europe for technical support and Lablicate, in particular Dr. Philip Wenig, for his support in handling the software OpenChrom for chemical data evaluation. We thank Prof. Dr. Erika von Mutius for her advisory support and manuscript revision. Furthermore, we thank Dr. Hendryk Czech and Dr. Uwe Käfer for their support on the statistical data evaluation and Dr. Christoph Bisig for his support on cell exposure experiments. We also like to thank the animal welfare officer of the cow shed from the Technical University Munich and all farmers who enabled aerosol sampling on their farms and in their animal sheds.

Author Contributions All authors contributed to the study conception and design. Material preparation, data collection and analysis were performed by NG, EJZ, JO and AH. The first draft of the manuscript was written by NG and all authors commented on previous versions of the manuscript. All authors read and approved the final manuscript.

Funding Open Access funding enabled and organized by Projekt DEAL. The authors did not receive support from any organization for the submitted work.

Data Availability Supplementary information will be available online after publication. Further datasets generated and/or analyzed during the current study are available from the corresponding author on reasonable request.

\section{Declarations}

Conflict of interest The authors have no relevant financial or non-financial interest to disclose.

Open Access This article is licensed under a Creative Commons Attribution 4.0 International License, which permits use, sharing, adaptation, distribution and reproduction in any medium or format, as long as you give appropriate credit to the original author(s) and the source, provide a link to the Creative Commons licence, and indicate if changes were made. The images or other third party material in this article are included in the article's Creative Commons licence, unless indicated otherwise in a credit line to the material. If material is not included in the article's Creative Commons licence and your intended use is not permitted by statutory regulation or exceeds the permitted use, you will need to obtain permission directly from the copyright holder. To view a copy of this licence, visit http://creativecommons.org/licenses/by/4.0/.

\section{References}

Abad MJ, Bedoya LM, Apaza L, Bermejo P (2012) The artemisia L. Genus: a review of bioactive essential oils. Molecules 17(3):25422566. https://doi.org/10.3390/molecules 17032542

Alfvén T, Braun-Fahrländer C, Brunekreef B, von Mutius E, Riedler J, Scheynius A, van Hage M, Wickman M, Benz MR, Budde J, Michels KB, Schram D, Ublagger E, Waser M, Pershagen 
G (2006) Allergic diseases and atopic sensitization in children related to farming and anthroposophic lifestyle - the PARSIFAL study. Allergy 61(4):414-421. https://doi.org/10.1111/j.13989995.2005.00939.x

Cait A, Cardenas E, Dimitriu PA, Amenyogbe N, Dai D, Cait J, Sbihi H, Stiemsma L, Subbarao P, Mandhane PJ, Becker AB, Moraes TJ, Sears MR, Lefebvre DL, Azad MB, Kollmann T, Turvey SE, Mohn WW (2019) Reduced genetic potential for butyrate fermentation in the gut microbiome of infants who develop allergic sensitization. J Allergy Clin Immunol 144(6):1638-1647.e1633. https://doi.org/10.1016/j.jaci.2019.06.029

Chary A, Hennen J, Klein SG, Serchi T, Gutleb AC, Blomeke B (2018) Respiratory sensitization: toxicological point of view on the available assays. Arch Toxicol 92(2):803-822. https://doi.org/10.1007/ s00204-017-2088-5

Cohen BM, Dressier WE (1982) Acute aromatics inhalation modifies the airways. Effects of the common cold. Respiration 43(4):285293. https://doi.org/10.1159/000194496

Dai M-Y, Chen F-F, Wang Y, Wang M-Z, Lv Y-X, Liu R-Y (2020) Particulate matters induce acute exacerbation of allergic airway inflammation via the TLR2/NF- $\mathrm{KB} / \mathrm{NLRP} 3$ signaling pathway. Toxicol Lett 321:146-154. https://doi.org/10.1016/j.toxlet.2019. 12.013

Debarry J, Garn H, Hanuszkiewicz A, Dickgreber N, Blumer N, von Mutius E, Bufe A, Gatermann S, Renz H, Holst O, Heine H (2007) Acinetobacter lwoffii and Lactococcus lactis strains isolated from farm cowsheds possess strong allergy-protective properties. J Allergy Clin Immunol 119(6):1514-1521. https://doi.org/10. 1016/j.jaci.2007.03.023

Delfino RJ, Staimer N, Vaziri ND (2011) Air pollution and circulating biomarkers of oxidative stress. Air Qual Atmos Health 4(1):3752. https://doi.org/10.1007/s11869-010-0095-2

Depner M, Taft DH, Kirjavainen PV, Kalanetra KM, Karvonen AM, Peschel S, Schmausser-Hechfellner E, Roduit C, Frei R, Lauener R, Divaret-Chauveau A, Dalphin JC, Riedler J, Roponen M, Kabesch M, Renz H, Pekkanen J, Farquharson FM, Louis P, Mills DA, von Mutius E, Ege MJ (2020) Maturation of the gut microbiome during the first year of life contributes to the protective farm effect on childhood asthma. Nat Med. https://doi.org/10.1038/ s41591-020-1095-x

Frei R, Ferstl R, Roduit C, Ziegler M, Schiavi E, Barcik W, Rodriguez-Perez N, Wirz OF, Wawrzyniak M, Pugin B, Nehrbass D, Jutel M, Smolinska S, Konieczna P, Bieli C, Loeliger S, Waser M, Pershagen G, Riedler J, Depner M, Schaub B, Genuneit J, Renz H, Pekkanen J, Karvonen AM, Dalphin JC, van Hage M, Doekes G, Akdis M, Braun-Fahrländer C, Akdis CA, von Mutius E, O'Mahony L, Lauener RP (2018) Exposure to nonmicrobial $\mathrm{N}$-glycolylneuraminic acid protects farmers' children against airway inflammation and colitis. J Allergy Clin Immunol 141(1):382390.e387. https://doi.org/10.1016/j.jaci.2017.04.051

Gkatzelis GI, Hohaus T, Tillmann R, Gensch I, Müller M, Eichler P, Xu KM, Schlag P, Schmitt SH, Yu Z, Wegener R, Kaminski M, Holzinger R, Wisthaler A, Kiendler-Scharr A (2018) Gas-toparticle partitioning of major biogenic oxidation products: a study on freshly formed and aged biogenic SOA. Atmos Chem Phys 18(17):12969-12989. https://doi.org/10.5194/acp-18-12969-2018

Gold MJ, Hiebert PR, Park HY, Stefanowicz D, Le A, Starkey MR, Deane A, Brown AC, Liu G, Horvat JC, Ibrahim ZA, Sukkar MB, Hansbro PM, Carlsten C, VanEeden S, Sin DD, McNagny KM, Knight DA, Hirota JA (2016) Mucosal production of uric acid by airway epithelial cells contributes to particulate matter-induced allergic sensitization. Mucosal Immunol 9(3):809-820. https:// doi.org/10.1038/mi.2015.104

Haahtela T, Holgate S, Pawankar R, Akdis CA, Benjaponpitak S, Caraballo L, Demain J, Portnoy J, von Hertzen L (2013) The biodiversity hypothesis and allergic disease: world allergy organization position statement. World Allergy Organ J 6(1):3. https://doi.org/ 10.1186/1939-4551-6-3

Haapakoski R, Karisola P, Fyhrquist N, Savinko T, Lehtimäki S, Wolff H, Lauerma A, Alenius H (2013) Toll-like receptor activation during cutaneous allergen sensitization blocks development of asthma through IFN-gamma-dependent mechanisms. J Investig Dermatol 133(4):964-972. https://doi.org/10.1038/jid.2012.356

Hara K, Iijima K, Elias MK, Seno S, Tojima I, Kobayashi T, Kephart GM, Kurabayashi M, Kita H (2014) Airway uric acid is a sensor of inhaled protease allergens and initiates type 2 immune responses in respiratory mucosa. J Immunol. https://doi.org/10. 4049/jimmunol.1400110

Hartl D, Tirouvanziam R, Laval J, Greene CM, Habiel D, Sharma L, Yildirim A, Dela Cruz CS, Hogaboam CM (2018) Innate immunity of the lung: from basic mechanisms to translational medicine. J Innate Immun 10(5-6):487-501. https://doi.org/10.1159/00048 7057

Horváth G, Ács K (2015) Essential oils in the treatment of respiratory tract diseases highlighting their role in bacterial infections and their anti-inflammatory action: a review. Flavour Fragr $\mathbf{J}$ 30(5):331-341. https://doi.org/10.1002/ffj.3252

Huff RD, Hsu ACY, Nichol KS, Jones B, Knight DA, Wark PAB, Hansbro PM, Hirota JA (2017) Regulation of xanthine dehydrogensase gene expression and uric acid production in human airway epithelial cells. PLoS ONE 12(9):e0184260. https://doi.org/10.1371/ journal.pone. 0184260

Hussain M, Madl P, Khan A (2011) Lung deposition predictions of airborne particles and the emergence of contemporary diseases, Part-I. Health 2(2):51-59

Illi S, Depner M, Genuneit J, Horak E, Loss G, Strunz-Lehner C, Büchele G, Boznanski A, Danielewicz H, Cullinan P, Heederik D, Braun-Fahrländer C, von Mutius E (2012) Protection from childhood asthma and allergy in Alpine farm environmentsthe GABRIEL Advanced Studies. J Allergy Clin Immunol 129(6):1470-1477.e1476. https://doi.org/10.1016/j.jaci.2012. 03.013

Jin W, Chang M, Sun SC (2012) Peli: a family of signal-responsive E3 ubiquitin ligases mediating TLR signaling and T-cell tolerance. Cell Mol Immunol 9(2):113-122. https://doi.org/10.1038/ cmi.2011.60

Kasperska-Zajac A (2010) Asthma and dehydroepiandrosterone (DHEA): facts and hypotheses. Inflammation 33(5):320-324. https://doi.org/10.1007/s10753-010-9188-1

Kim J-S, Chung HY (2009) GC-MS analysis of the volatile components in dried boxthorn (Lycium chinensis) fruit. J Korean Soc Appl Biol Chem 52(5):516-524. https://doi.org/10.3839/ jksabc. 2009.088

Kool M, Willart MA, van Nimwegen M, Bergen I, Pouliot P, Virchow JC, Rogers N, Osorio F, Reis e SousaHammadLambrecht CHBN (2011) An unexpected role for uric acid as an inducer of T helper 2 cell immunity to inhaled antigens and inflammatory mediator of allergic asthma. Immunity 34(4):527-540. https:// doi.org/10.1016/j.immuni.2011.03.015

Koziol-White CJ, Goncharova EA, Cao G, Johnson M, Krymskaya VP, Panettieri RA Jr (2012) DHEA-S inhibits human neutrophil and human airway smooth muscle migration. Biochim Biophys Acta 1822(10):1638-1642. https://doi.org/10.1016/j.bbadis. 2012.06.012

Lambrecht BN, Hammad H (2017) The immunology of the allergy epidemic and the hygiene hypothesis. Nat Immunol 18(10):1076-1083. https://doi.org/10.1038/ni.3829

Lee HS, Park DE, Song WJ, Park HW, Kang HR, Cho SH, Sohn SW (2016) Effect of 1.8-cineole in Dermatophagoides pteronyssinus-stimulated bronchial epithelial cells and mouse model of asthma. Biol Pharm Bull 39(6):946-952. https://doi.org/10. 1248/bpb.b15-00876 
Livak KJ, Schmittgen TD (2001) Analysis of relative gene expression data using real-time quantitative PCR and the 2(-Delta Delta C(T)) method. Methods 25(4):402-408. https://doi.org/ 10.1006/meth.2001.1262

Loss G, Bitter S, Wohlgensinger J, Frei R, Roduit C, Genuneit J, Pekkanen J, Roponen M, Hirvonen MR, Dalphin JC, Dalphin ML, Riedler J, von Mutius E, Weber J, Kabesch M, Michel S, Braun-Fahrländer C, Lauener R (2012) Prenatal and early-life exposures alter expression of innate immunity genes: the PASTURE cohort study. J Allergy Clin Immunol 130(2):523-530. e529. https://doi.org/10.1016/j.jaci.2012.05.049

Mason YC, Schoonraad G-L, Orasche J, Bisig C, Jakobi G, Zimmermann R, Forbes PBC (2020) Comparative sampling of gas phase volatile and semi-volatile organic fuel emissions from a combustion aerosol standard system. Environ Technol Innov 19:100945. https://doi.org/10.1016/j.eti.2020.100945

Mutzel A, Rodigast M, Iinuma Y, Böge O, Herrmann H (2016) Monoterpene SOA - contribution of first-generation oxidation products to formation and chemical composition. Atmos Environ 130:136-144. https://doi.org/10.1016/j.atmosenv.2015.10. 080

Nordgren TM, Friemel TD, Heires AJ, Poole JA, Wyatt TA, Romberger DJ (2014) The omega-3 fatty acid docosahexaenoic acid attenuates organic dust-induced airway inflammation. Nutrients 6(12):5434-5452. https://doi.org/10.3390/nu6125434

Olivera ER, Luengo JM (2019) Steroids as environmental compounds recalcitrant to degradation: genetic mechanisms of bacterial biodegradation pathways. Genes (Basel). https://doi.org/10.3390/ genes 10070512

Orasche J, Schnelle-Kreis J, Abbaszade G, Zimmermann R (2011) Technical note: in-situ derivatization thermal desorption GCTOFMS for direct analysis of particle-bound non-polar and polar organic species. Atmos Chem Phys 11(17):8977-8993. https:// doi.org/10.5194/acp-11-8977-2011

Pawankar R (2014) Allergic diseases and asthma: a global public health concern and a call to action. World Allergy Organ J 7(1):12. https://doi.org/10.1186/1939-4551-7-12

Peters M, Kauth M, Schwarze J, Körner-Rettberg C, Riedler J, Nowak D, Braun-Fahrländer C, von Mutius E, Bufe A, Holst O (2006) Inhalation of stable dust extract prevents allergen induced airway inflammation and hyperresponsiveness. Thorax 61(2):134-139. https://doi.org/10.1136/thx.2005.049403

Pyrhönen K, Kulmala P, Näyhä S, Läärä E (2019) Diverse age-incidence patterns of atopic sensitization in an unselected Finnish population up to 12 years. Ann Allergy Asthma Immunol 122(5):522-531.e523. https://doi.org/10.1016/j.anai.2019.02.027

Reinmuth-Selzle K, Kampf CJ, Lucas K, Lang-Yona N, FrohlichNowoisky J, Shiraiwa M, Lakey PSJ, Lai S, Liu F, Kunert AT, Ziegler K, Shen F, Sgarbanti R, Weber B, Bellinghausen I, Saloga
J, Weller MG, Duschl A, Schuppan D, Poschl U (2017) Air pollution and climate change effects on allergies in the anthropocene: abundance, interaction, and modification of allergens and adjuvants. Environ Sci Technol 51(8):4119-4141. https://doi.org/10. 1021/acs.est.6b04908

Roduit C, Frei R, Ferstl R, Loeliger S, Westermann P, Rhyner C, Schiavi E, Barcik W, Rodriguez-Perez N, Wawrzyniak M, Chassard C, Lacroix C, Schmausser-Hechfellner E, Depner M, von Mutius E, Braun-Fahrländer C, Karvonen AM, Kirjavainen PV, Pekkanen J, Dalphin JC, Riedler J, Akdis C, Lauener R, O’Mahony L (2019) High levels of butyrate and propionate in early life are associated with protection against atopy. Allergy 74(4):799-809. https://doi. org/10.1111/all.13660

Rutkowski K, Sowa P, Rutkowska-Talipska J, Kuryliszyn-Moskal A, Rutkowski R (2014) Dehydroepiandrosterone (DHEA): hypes and hopes. Drugs 74(11):1195-1207. https://doi.org/10.1007/ s40265-014-0259-8

Schuijs MJ, Willart MA, Vergote K, Gras D, Deswarte K, Ege MJ, Madeira FB, Beyaert R, van Loo G, Bracher F, von Mutius E, Chanez P, Lambrecht BN, Hammad H (2015) Farm dust and endotoxin protect against allergy through A20 induction in lung epithelial cells. Science 349(6252):1106-1110. https://doi.org/10. $1126 /$ science.aac6623

Sozańska B (2019) Raw cow's milk and its protective effect on allergies and asthma. Nutrients. https://doi.org/10.3390/nu11020469

Tan J, McKenzie C, Potamitis M, Thorburn AN, Mackay CR, Macia L (2014) The role of short-chain fatty acids in health and disease. Adv Immunol 121:91-119. https://doi.org/10.1016/b978-0-12800100-4.00003-9

Weggler BA, Ly-Verdu S, Jennerwein M, Sippula O, Reda AA, Orasche J, Gröger T, Jokiniemi J, Zimmermann R (2016) Untargeted identification of wood type-specific markers in particulate matter from wood combustion. Environ Sci Technol 50(18):10073-10081. https://doi.org/10.1021/acs.est.6b01571

Yu CK, Yang BC, Lei HY, Chen YC, Liu YH, Chen CC, Liu CW (1999) Attenuation of house dust mite Dermatophagoides farinaeinduced airway allergic responses in mice by dehydroepiandrosterone is correlated with down-regulation of $\mathrm{TH} 2$ response. Clin Exp Allergy 29(3):414-422. https://doi.org/10.1046/j.1365-2222. 1999.00484.x

Zakeri A, Russo M (2018) Dual role of toll-like receptors in human and experimental asthma models. Front Immunol 9:1027. https:// doi.org/10.3389/fimmu.2018.01027

Publisher's Note Springer Nature remains neutral with regard to jurisdictional claims in published maps and institutional affiliations. 